Universidade de Brasília

Centro de Excelência em Turismo

TURISMO NA TERCEIRA IDADE: UM ESTUDO SOBRE A CAPACITAÇÃO DE PROFISSIONAIS

Daniele Linhares Galvão Carneiro da Cunha 
Universidade de Brasília

Centro de Excelência em Turismo

Curso de Especialização em Gestão e Marketing do Turismo

\title{
TURISMO NA TERCEIRA IDADE: UM ESTUDO SOBRE A CAPACITAÇÃO DE PROFISSIONAIS
}

\author{
Daniele Linhares Galvão Carneiro da Cunha
}

Domingos Sávio Spezia, Msc

Orientador

Monografia apresentada ao Centro de Excelência em Turismo da Universidade de Brasília como requisito parcial para a obtenção do certificado de Especialista em Gestão e Marketing do Turismo.

Brasília, DF, Março de 2004 
UNIVERSIDADE DE BRASÍLIA

Centro de Excelência em Turismo

Curso de Especialização em Gestão e Marketing do Turismo

\title{
TURISMO NA TERCEIRA IDADE: UM ESTUDO SOBRE A CAPACITAÇÃO DE PROFISSIONAIS
}

\author{
Daniele Linhares Galvão Carneiro da Cunha
}

\begin{tabular}{c}
\hline Domingos Sávio Spezia \\
Orientador \\
Mestre em Administração Pública \\
\hline Carlos José Rodrigues da Silva \\
Examinador \\
Mestre em Administração
\end{tabular}

Brasília, DF, 22 de Março de 2004. 


\section{DANIELE LINHARES GALVÃO CARNEIRO DA CUNHA}

Turismo Na Terceira Idade: um estudo sobre a capacitação de profissionais

Comissão Avaliadora

Domingos Sávio Spezia

Orientador

Mestre em Administração Pública

Carlos José Rodrigues da Silva

Examinador

Mestre em Administração

Brasília, DF, 22 de Março de 2004. 
Ao meu Rei, Jorge André. 
Agradeço ao meu pai, Francisco Lúcio de Matos Galvão pelo apoio em todos os momentos em que precisei de uma mão amiga.

Ao meu irmãozinho Caio Linhares Prujansky; a sua lembrança me alegrou nos momentos em que tudo parecia tão difícil e me fez ver os problemas com a simplicidade de uma criança.

Aos colegas acadêmicos, pelas horas de luta empreendidas em conjunto.

Ao corpo de Professores e Servidores do Curso de Especialização Gestão e Marketing do Turismo da Universidade de Brasília.

Ao meu orientador Domingos Sávio Spezia, pela habilidade e paciência em me conduzir para a concretização deste trabalho.

A todos que contribuíram de uma maneira ou de outra para o meu desenvolvimento pessoal e profissional.

Em especial, ao meu esposo Jorge André Carneiro da Cunha, por tudo o que ele representa dentro do meu coração, por toda a paciência em revisar este trabalho e por me motivar a cada dia amá-lo mais.

A todos os velhos nos quais encontrei a juventude de um pôr do sol e o ardor de um jovem.

E a Deus, Criador, Inspirador e Paráclito que me inspira a fazer este trabalho com amor. 
"Envelhecer é morrer um pouco.

Na efêmera viagem da matéria.

É exaurir a vida que palpita

No pulsar do coração.

No movimento das células.

No corpo que caminha

E no cérebro que comanda.

Envelhecer é sentir a carícia da neve.

Acordando histórias nos cabelos brancos.

É aflorar a experiência das lições da vida

É soltar, como se fossem pássaros.

As reservas de amor que o tempo aprisionou.

Envelhecer é chegar ao topo da escalada

E olhar, sorrindo, a vida que passou.

É no espírito pleno de energia.

Na madrugada que antecede o amanhecer.

É no encontro da esperança com a saudade.

É morrer, um pouco, para o mundo

E renascer, aos poucos, para a eternidade.".

(Newton Rossi) 


\section{Resumo}

A fim de investigar a importância da capacitação dos profissionais do turismo para o desenvolvimento da atividade turística junto ao público da terceira idade foram percorridos alguns tópicos: primeiramente foi abordado o turismo, sua história, conceitos, definições e a importância econômica como um meio para o entendimento do quanto o turismo, como atividade profissional, vem crescendo no Brasil. Em seguida, trata-se da terceira idade, da origem do termo, dos aspectos biológicos, psíquicos e sociais do idoso, das leis a eles dedicadas, do levantamento da população idosa mundial e de sua participação na economia. O estudo desse capítulo leva à constatação de que o idoso é, normalmente, uma pessoa com tempo livre e maior disponibilidade de receita para gastar em viagens trazendo à atividade turística, a preocupação de capacitar recursos humanos para lidar com esse público em virtude de suas necessidades peculiares, em relação a outros segmentos de mercado. Posteriormente, aborda-se a importância do lazer e do turismo para o idoso, já que o lazer, nessa etapa, revaloriza a sua vida social. Por fim, traz-se à tona a importância da capacitação dos profissionais do turismo para o desenvolvimento da atividade turística com a terceira idade. O idoso é um público que requer cuidados constantemente. O investimento na mão-de-obra especializada parece ser a forma mais correta para a qualificação da prestação de serviços a este grupo populacional. Esta pesquisa procura mostrar que a qualificação da mão-de-obra especializada para o desenvolvimento da atividade turística junto ao público da terceira idade é o grande diferencial para o Brasil atingir a competitividade nesse segmento.

1. Turismo. 2. Terceira Idade. 3. Lazer e Turismo na Terceira Idade. 4. Educação 


\begin{abstract}
In order to investigate the importance of qualifying the tourism professionals for the development of the touristic activity to the the third age people, some subjects had been covered: first there is an approach on tourism, its history, concepts, definitions and the economic importance as a way for the agreement of how much the tourism, as professional activity, has grown in Brazil. After that, one is to the third age, the origin of the term, of the biologic, psiquic and social aspects of the aged ones, the laws dedicated to them, the survey of aged population world-wide and its participation in the economy. The study of this chapter takes constatation of that the aged are, usually, people with free time and more money availability to spend in trips, causing touristic activity motivation to enable human resources to deal with this people in virtue of its peculiar necessities, comparing to other segments of market. Later, the importance of leisure and tourism for the aged one is approached, as long as the leisure, in this stage, gives purpose to their social life. Finally, it is showed the importance of enableing tourism professionals for the development of the touristic activity with the third age. The aged one requires cares constantly. The investment in the specialized workmanship seems to be the most correct way for qualifying the service to this population group. This research looks for showing that qualifying specialized workmanship for the development of touristic activity to the third aged is the great way to Brazil reach the competitiveness in this segment.
\end{abstract}

1, Tourism. 2. Third Age. 3. Leisure and Tourism in Third Age. 4. Education 


\section{Sumário}

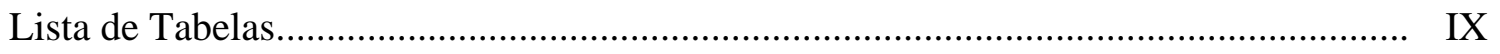

Lista de Abreviaturas............................................................................................. X

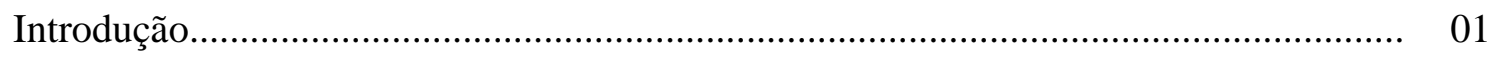

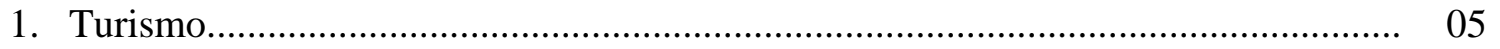

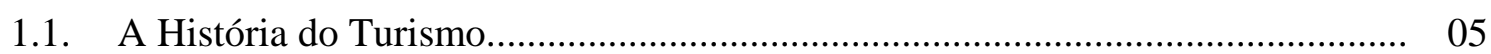

1.2. Turismo: Conceitos e Definições...................................................................... 12

1.3. Importância Social e Econômica do Turismo.................................................... 19

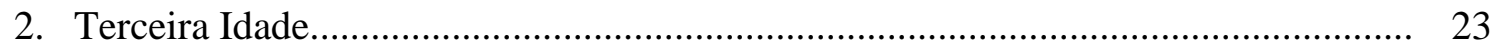

2.1. Origem dos Termos............................................................................... 25

2.2. Aspectos Biopsicossociais da Velhice......................................................... 30

2.3. Estatísticas do Aumento do Envelhecimento da População no Mundo e no

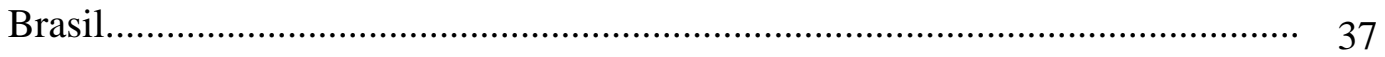

3. Lazer e Turismo na Terceira Idade........................................................................... 43

3.1. Leis e Políticas que Favorecem a Realização do Lazer e do Turismo aos Idosos. 51

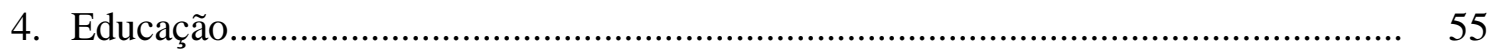

4.1. A LDB e a Educação Profissional......................................................................... 59

4.2. Educação para o Turismo.................................................................................. 66

4.3. Levantamento da Oferta de Cursos na Área do Turismo no Brasil....................... 73

5. Análise e Discussão dos Resultados.................................................................. 81

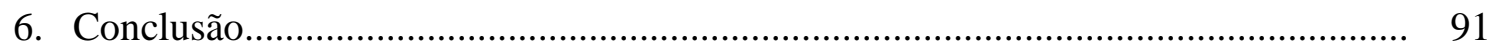

Referências Bibliográficas......................................................................................... 94

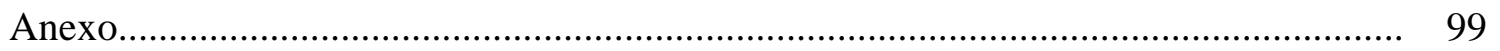




\section{Lista Tabelas}

Tabela 01: População e a estimativa de idosos do Brasil em relação a outros países de 1996 a $2025 .$.

Tabela 02: Rendimento médio mensal das pessoas com 60 anos ou mais de idade responsáveis pelo domicílio, com rendimento e respectivo crescimento relativo, segundo as Grandes Regiões - 1991 - 2000.

Tabela 03: Cursos de bacharelado especificamente na área de turismo e hotelaria no Brasil por Estado - 2002

Tabela 04: Distribuição de oferta de cursos de bacharelado especificamente em turismo e hotelaria por região brasileira: 1994, 1996, 2000 e 2002.

Tabela 05: Cursos de bacharelado em administração com habilitação em turismo e hotelaria no Brasil por Estado - 2002

Tabela 06: Cursos tecnológicos em turismo e hotelaria no Brasil por Estado - 2002..... 78

Tabela 07: Cursos seqüenciais em turismo e hotelaria no Brasil por Estado - 2002....... 79 


\section{Lista de Abreviaturas}

ABCMI Associação Brasileira dos Clubes da Melhor Idade

ABE .Associação Brasileira de Educação

CEFET'S ..Centros Federais de Educação Tecnológica

EMBRATUR. .Instituto Brasileiro de Turismo

IATA Associação do Transporte Aéreo Internacional

IBGE. .Instituto Brasileiro de Geografia e Estatística

INATEL .Instituto Nacional de Aproveitamento dos Tempos Livres

IUOTO. .União Internacional de Organismos Oficiais de Turismo

LDB .Lei das Diretrizes e Bases da Educação Nacional MOBRAL Movimento Brasileiro de Alfabetização MEC. ..Ministério da Educação

MERCOSUL Mercado Comum do Sul

OMS .Organização Mundial de Saúde

OMT. Organização Mundial do Turismo

ONU .Organizações das Nações Unidas

PIB Produto Interno Bruto

PROEP Programa de Expansão da Educação Profissional

PNAD. .Pesquisa Nacional por Amostra de Domicílios

SEBRAE. Serviço Brasileiro de Apoio às Micro e Pequenas Empresas SENAC. Serviço Nacional de Aprendizagem Comercial SENAI. Serviço Nacional de Aprendizagem Industrial SESC Serviço Social do Comércio UF Unidades da Federação UNISUL .Universidade do Sul de Santa Catarina 
Cunha, Daniele Linhares Galvão Carneiro da

Turismo na Terceira Idade: um estudo sobre a capacitação para os profissionais desta área / Daniele Linhares Galvão Carneiro da Cunha.

$109 \mathrm{f}$.

Monografia - Especialização em Gestão e Marketing do Turismo Universidade de Brasília. Centro de Excelência de Turismo. Brasília, 2004.

Tourism in the Third Age: a search on the qualification for the professionals of this area.

Área de concentração: Turismo

Orientador: Domingos Sávio Spezia, Msc.

1. Turismo. 2. Terceira Idade. 3. Educação. 4. Capacitação. - Monografia. 


\section{Introdução}

O turismo, de acordo com Oliveira (2001, p. 44), é considerado a atividade econômica que mais se desenvolve no mundo, ocupando uma importante posição entre os três segmentos mais influentes no comércio mundial, juntamente com o petróleo e a indústria automobilística. A atividade turística gera fenômenos de consumo originando rendas, e criando mercados nos quais a oferta e a procura se encontram.

Segundo o $7^{\circ}$ Encontro dos Clubes da Melhor Idade e $6^{\circ}$ Encontro LusoBrasileiro da Melhor Idade ${ }^{1}$, em Fortaleza - CE o turismo na terceira idade é uma forma de promover o crescimento econômico brasileiro.

A terceira idade foi escolhida para ser objeto deste estudo baseado em dados colhidos nas projeções realizadas pelo Instituto Brasileiro de Geografia e Estatística IBGE $^{2}$, que apontam o crescimento da população idosa. Esse é um fenômeno global. As projeções indicam que, em 2050, a população idosa será de 1,9 bilhão de pessoas, ou seja, 23\% da população mundial, o que eqüivalerá à população infantil de 0 a 14 anos de idade, significando um grande acréscimo em relação aos 9\% atuais. Esse fenômeno se dá pelo aumento, verificado desde 1950, de 19 anos na esperança de vida, ao nascer, em todo o mundo.

Ainda de acordo com a Home Page do IBGE, verifica-se que a população com sessenta anos ou mais representou, no ano 2002, 8,6\% da população brasileira, com um rendimento médio mensal de seiscentos e cinqüenta e sete reais. O Distrito Federal e o Rio de Janeiro são as unidades da federação que possuem os maiores rendimentos médios para os idosos (R\$ 1.796,00 e R\$1.018,00, respectivamente), seguidos pelos demais estados da região Sudeste e Sul.

\footnotetext{
${ }^{1}$ Assessoria de Comunicação Social, www.met.gov.br/notícias, acesso em: 19 set. 2002

${ }^{2}$ Home Page do IBGE, http://www.ibge.gov.br/ibgeteen/datas/idoso/ perfil_idosos.html, acesso em: 04 set. 2003
} 
Com base nas afirmações acima descritas, observa-se a importância do idoso no desenvolvimento da atividade turística no Brasil pois, nesta fase da vida, o indivíduo desfruta de mais tempo e recursos financeiros para a retomada de antigos projetos ou para a concepção de novos, já que diminuem as suas obrigações profissionais e a família não requer mais atenção tão significativa. O lazer, nesse momento, é um meio de proporcionar ao ancião a complementação de suas necessidades.

Para suprir essa perene necessidade de consumo, o governo brasileiro e os empresários com interesses na área já investem nesse segmento de mercado. O Ministério da Indústria, do Comércio e do Turismo tem uma participação ativa na Política Nacional do Idoso através da Instituto Brasileiro de Turismo - EMBRATUR. Esse órgão trabalha no desenvolvimento do programa Clube da Melhor Idade, tendo essa como uma ação prioritária com o objetivo de permitir a melhora na qualidade de vida para os brasileiros maiores de 50 anos através do lazer e do turismo ${ }^{3}$. (Second International Conference on Senior Tourism, 1996, p. 02)

Segundo Silva (2002, p. 09), alguns transportadores aéreos já incentivam viagens para maiores de 55 anos, proporcionando a esse público descontos na baixa estação de $45 \%$ e na alta estação de $30 \%$ no preço de suas passagens para viagens nacionais, como é o caso da empresa aérea Varig.

Ainda de acordo com Silva (2002, p. 10), apesar dessas iniciativas, à primeira vista, parecerem um esforço no investimento desse segmento, o que se percebem, na realidade, são adaptações da programação destinada ao público em geral para minimizar os efeitos da baixa estação. Essa programação é aceita pelo idoso como única forma de viajar.

\footnotetext{
${ }^{3}$ The Ministry of Industry, Trade and Tourism is an active participant in this policy (National Policy for the Elderly) through EMBRATUR, the Brazilian Tourism Board. EMBRATUR works in the development of the Senior Club Programme. It is a priority action. Its objective is to enable better quality of life through leisure and tourism for the Brazilians of over 50 years of age.
} 
Nos últimos anos, muitos são os estudos voltados para a melhoria da qualidade de vida, aumento da expectativa de vida, educação da terceira idade, gerontologia e geriatria. Poucos são os estudos voltados para o turismo na terceira idade.

A promoção da capacitação dos profissionais de turismo para a otimização da prestação de serviços ao idoso poderá proporcionar um atendimento de qualidade e estruturado para as necessidades psicossociais desse público. Em face dessas preocupações surgiu a seguinte questão: é pertinente a capacitação do profissional do turismo para a otimização do atendimento ao idoso?

Com este estudo será possível discutir o quanto a educação e os órgãos de turismo, no Brasil, estão desenvolvendo esforços na qualificação de profissionais para o turismo da terceira idade.

O objetivo geral deste estudo é investigar a importância da capacitação dos profissionais do turismo para o desenvolvimento da atividade turística junto ao público da terceira idade. Para alcançar esse objetivo geral foram percorridos os seguintes objetivos específicos: demonstração da existência de demanda para o turismo da terceira idade; identificação da importância da capacitação dos profissionais do turismo para o desenvolvimento da atividade turística com o público sênior e verificação da oferta de qualificação profissional para agentes de turismo voltados para o idoso.

O desenvolvimento do tema proposto foi realizado através de uma pesquisa de cunho bibliográfico que, de acordo com Costa, M. (2001, p. 63), “é aquela realizada em livros, revistas, jornais, etc. Ela é básica para qualquer tipo de pesquisa...”.

...este tipo de pesquisa busca explicar um problema com base em contribuições teóricas publicadas em documentos (livros, revistas, jornais etc.) e não por intermédio de relatos de pessoas ou experimentos. Pode ser realizada de forma independente ou estar inserida (levantamento bibliográfico) nos demais tipos de pesquisas.

(Traldi e Dias, 2001, p. 43) 
O enfoque da análise utilizou a abordagem qualitativa, buscando compreensão da importância em capacitar profissionais para o desenvolvimento do turismo da terceira idade.

A pesquisa foi realizada nos seguintes locais: Biblioteca do Centro de Excelência em Turismo da Universidade de Brasília, Biblioteca da Universidade de Brasília, Biblioteca da Universidade Federal de Santa Catarina, Biblioteca da Universidade do Sul de Santa Catarina, Biblioteca da Universidade Estadual de Santa Catarina, Clubes de terceira idade, Ministério da Educação - MEC, entre outros ambientes em que se possam obter informações para o embasamento da pesquisa. Foram utilizados dados secundários através do MEC, do IBGE - Censos e na Rede Mundial dos Computadores.

Com a finalidade de fundamentar o presente estudo e para melhor compreensão do assunto, o trabalho foi organizado em cinco tópicos. Inicia-se abordando o turismo, suas definições e importância social. Em seguida, trata-se da terceira idade, da origem do termo, dos tratamentos dispensados a esse segmento ao longo dos anos, dos aspectos biopsicossociais do idoso, das leis dispensadas aos idosos, do levantamento da população idosa mundial e de sua participação econômica na população total do Brasil. Posteriormente, investiga-se o turismo e o idoso. Ato contínuo, aborda-se a existência de oferta de profissionais de turismo capacitados para o atendimento à terceira idade e traz-se à tona a importância da capacitação de profissionais do turismo para o desenvolvimento da atividade turística com a terceira idade e analisam-se os resultados.

A análise e o confronto entre as teorias existentes sobre o tema levaram à elaboração de um estudo conciso direcionado aos profissionais e acadêmicos da área de turismo e hospitalidade, procurando conscientizá-los de que é necessário investir em qualificação profissional voltada para o turismo da terceira idade com o fim de conquistar esse nicho de mercado. 


\section{Turismo}

\section{1. A História do Turismo}

Oliveira (2001, p. 15) afirma que a palavra tour em francês quer dizer volta, tendo seu equivalente turn, no inglês, do latim tornare. As palavras tourism e tourist, de origem inglesa, aparecem documentadas em 1760, na Inglaterra. O suíço Arthur Haulot, um estudioso do turismo, apresenta a possibilidade da origem hebraica da palavra tour, viagem de ida e volta, quando, na Bíblia - Capítulo XII, versículo17 (sic), cita que "Moisés enviou um grupo de representantes ao país de Canaã para visitá-los e informar-se a respeito de suas condições topográficas, demográficas e agrícolas”. Ele afirma que Tur é hebraico antigo, e corresponde ao conceito de "viagem de descoberta, de exploração, de reconhecimento".

Ainda de acordo com Oliveira (2001, p. 15), há autores que defendem que o começo do turismo se deu a partir do século VIII a.C., na Grécia, com os Jogos Olímpicos, que acolhiam um grande número de pessoas vindas das mais distintas regiões. Tempos depois, se intensificaram com a descoberta das propriedades de cura das águas minerais. $\mathrm{O}$ mesmo autor afirma que os fenícios foram os inventores da moeda e do comércio dando, desta forma, o primeiro passo para tornar mais fácil e mais seguras as viagens. Os viajantes não precisavam mais levar consigo prata, ouro e pedras preciosas para pagar suas contas, trocando-os, assim, pelas moedas.

Segundo Leakey apud Barretto (1995, p. 44), se fosse realizada uma pesquisa em tempos anteriores ao greco-romano, encontrar-se-iam antecedentes ainda mais remotos, chegando-se a supor que o ser humano sempre viajou, seja definitivamente (migrando) ou temporariamente. Pesquisas arqueológicas demonstram que há três mil anos, grupos humanos, habitantes da Caverna de Madasin, nos Pirineus franceses, viajavam até o mar e retornavam.

Oliveira (2001, p. 18) relata que os romanos também podem ser citados nos antecedentes remotos do turismo. Estradas foram construídas durante o Império Romano 
(27 a.C. e 476 d.C.), permitindo, assim, a existência de viagens com maior intensidade. Viajavam por lazer, comércio e para conquistar outras regiões. Instalaram, ao longo das estradas uma infra-estrutura que continha hospedarias; as "mansiones", albergues que serviam, sobretudo, aos "cursos publicus" (serviço postal); e as "stationes", chamadas também de “mutationes", que serviam para troca de cavalos, localizadas ao longo das estradas, a cada 40 ou 50 quilômetros, e nos centros de tratamento termal. Os romanos, considerados os primeiros a viajar por prazer, tinham em seus espetáculos circenses e nas lutas em arenas suas grandes atrações de entretenimento e recreação.

Com a queda do Império Romano, as estradas foram destruídas e ocorreu um grande declínio do comércio. As viagens de prazer acabaram. A motivação de viajar foi reduzida drasticamente devido às invasões dos povos bárbaros aos territórios romanos. Apesar disso, o movimento nas estradas foi marcado por um tipo de viajante: o peregrino.

Segundo Castelli (1996, p. 16), durante a Idade Média ${ }^{4}$, os interesses religiosos tornaram-se a mola propulsora das longas viagens. Levas de cristãos se dirigiam a Jerusalém, Roma e a Santiago de Compostela, sem falar nas levas de muçulmanos para Meca. A cidade de Santiago de Compostela foi, para os cristãos, o lugar mais importante de peregrinação depois de Roma e Jerusalém.

Conforme Oliveira (2001, p.19), na Idade Média, com o surgimento do sistema feudalista, a sociedade estava composta, de um lado, pelos senhores feudais (proprietários de terras) e do outro pelos servos (que cultivavam as terras dos proprietários e lhes davam metade de sua produção). Tendo como base a agricultura, cada feudo era auto-suficiente e as populações se fixavam junto aos feudos, não existindo assim deslocamentos para fora dos feudos pois não havia comércio a se praticar. Nesse período, só viajava quem tinha extrema necessidade, pois as estradas dos romanos estavam perigosas e abandonadas.

As Cruzadas, organizadas, inicialmente, para recuperar o Santo Sepulcro, em Jerusalém, reiniciaram os deslocamentos de viajantes, peregrinos, soldados e mercadores

\footnotetext{
${ }^{4}$ Período compreendido entre 476, queda do Império Romano e 1453, tomada de Constantinopla pelos turcos.
} 
em todo o território europeu. As pousadas, antes caridosas (não cobravam os pernoites), transformaram-se em atividades lucrativas, passando a cobrar os serviços prestados.

A tomada de Constantinopla (atual Istambul) pelos turcos em 1453, fez com que surgisse a necessidade de encontrar novos caminhos para o Oriente. Isso provocou o começo das viagens transoceânicas, que utilizavam as caravelas como meio de transporte. Foram os portugueses e espanhóis que deram os primeiros passos para mostrar a existência de um novo mundo e a despertar, nos europeus, a curiosidade de conhecê-lo.

Do século XVI ao XVIII, as grandes navegações impulsionaram as viagens de longo percurso, antecipando o período denominado "turismo moderno".

Castelli (1996, p. 17) menciona que no final do século XVI o Renascimento desenvolveu as artes, as letras, as ciências e promoveu mudanças nos costumes, especialmente dos artistas e artesãos, que se locomoviam de cidade em cidade, por toda Europa, para edificarem e pintarem palácios, igrejas e outros monumentos. Os músicos e atores também freqüentavam continuamente nas estradas, visitando diversas cidades para suas apresentações. O Renascimento trouxe um grande incentivo para as viagens, surgindo os "tours", realizados, sobretudo, pela aristocracia inglesa como complemento à sua formação.

Segundo Barretto (1995, p. 48), o comércio entre a Europa e o Oriente tomou um novo impulso e os mercadores reiniciaram suas viagens no século XVI. Novidades surgiram como: o primeiro hotel do mundo, o Wekalet-Al-Ghury, no Cairo (Egito), para atender os mercadores $\mathrm{Na}$ Itália apareceram as primeiras carruagens que tinham mais luxo do que conforto.

No mesmo século registravam-se 12 spas na Europa para pobres e doentes, com programas de entretenimento. Os turistas começaram a se misturar aos doentes para desfrutar da recreação organizada. Apareceram pouco a pouco os spas exclusivamente para ricos e nobres. 
Ainda no século XVI, teve início, na França, a realização dos dois tipos de viagem de lazer que caracterizaram os primeiros tempos do turismo: o Petit Tour e o Grand Tour. O primeiro consistia numa visita ao Vale do Loire e retorno a Paris. O segundo, do final do século XVII às últimas décadas do século XVIII, complementava a formação dos jovens ingleses e estendia-se, pela França, Suíça e Itália, em especial às cidades de Paris, Roma, Genebra, Florença, Milão, Bolonha, Veneza e Nápoles, sempre acompanhados por um cicerone que conhecia bem a história dos locais visitados.

(Oliveira, 2001, p. 21)

Os meios de transporte evoluíram notavelmente no século XVII. Apareceram publicações com o objetivo de orientar os turistas. De acordo com Castelli (2001, p. 18/20), Francis Bacon escreve “Of Travel”, em 1612, que traz uma série de indicações e conselhos para os viajantes.

O mesmo autor aponta que a Reforma Protestante ${ }^{5}$ e a Revolução Industrial marcaram o início do capitalismo organizado. O primeiro período foi denominado de “turismo neoclássico”, no qual a viagem era um aprendizado, complemento indispensável à educação. Mudanças estavam sendo processadas. Buscava-se, em outros países, informações sobre os avanços no comércio, na agricultura e nos manufaturados, com o objetivo de desenvolver a própria profissão. Enquanto na aristocracia as viagens faziam parte da formação, na burguesia elas se inseriam dentro de uma visão profissional.

Ainda de acordo com o autor citado acima, o século XVIII caracteriza-se por um movimento que vem a favorecer as viagens: o romantismo. Exalta-se tudo o que é natural. O romantismo despertou nas classes mais cultas uma nova visão de natureza. Chamou atenção para as suas belezas. Todos os valores naturais significativos transformaram-se em motivos de viagens.

\footnotetext{
${ }^{5}$ Reforma Protestante: crise religiosa do século XVI que dividiu a igreja do ocidente em dois campos: o católico e o protestante. (Barsa, 1991, vol. 13, p. 322)
} 
A necessidade de agilizar o transporte das correspondências também contribuiu para o desenvolvimento dos transportes e das viagens a turismo. John Palmer, em 1784, introduziu a diligência para o transporte de cartas e de alguns passageiros.

A Itália continuava a ser o roteiro predileto, no final do século XVIII e início do século XIX, embora as viagens tenham sido ampliadas para a Espanha, Grécia e países do Oriente. Nessa época, principalmente no século XIX, uma modalidade de lazer que na era dos romanos tinha atingido um momento de alta prosperidade foi reativada: os balneários. Eles voltaram a ser procurados não pelos aspectos curativos, mas pela oportunidade de diversão que ofereciam.

De acordo com Oliveira (2001, p. 24), o turismo tomou novos caminhos, entrando para a etapa do chamado "turismo romântico". Voltam a apreciação das paisagens, a contemplação da natureza e a necessidade do descanso. Esse novo comportamento humano decorre da deterioração da qualidade de vida nos grandes centros urbanos e industriais. As pessoas passaram a necessitar de períodos de descanso para recuperar as forças perdidas.

Ainda no século XIX, o turismo adquiriu um novo estilo provocado pelo desenvolvimento tecnológico, aumento dos ganhos por parte dos trabalhadores e facilidades que os meios de transporte da época ofereciam. Esses fatores permitiram que o turismo tomasse um extraordinário impulso; o transporte de pessoas passou a ter importante valor econômico.

A ferrovia Liverpool-Manchester, na Inglaterra, em 1830, passou a dedicar mais atenção aos passageiros do que às cargas, iniciando-se a era das ferrovias como fator determinante do desenvolvimento do turismo.

No decorrer do mesmo século, Castelli (1996, p. 21) relata o surgimento do inglês Thomas Cook, que dá inicio à comercialização do turismo. Despontam as primeiras empresas do ramo. Com as inovações trazidas pela Revolução Industrial (nos campos 
tecnológico e político), o turismo passa a ganhar cada vez mais adeptos. Foi o começo do turismo coletivo: a "excursão organizada” que atualmente leva o título de all inclusive 6 ou pacote.

Outros fatores contribuíram para que o turismo continuasse a desenvolver-se ao longo do século XIX. Esses fatores foram, segundo Barretto (1995, p.53), a segurança, que foi proporcionada pelo estabelecimento de polícias de fronteira; a salubridade, advinda do tratamento das águas e instalações de esgotos em várias cidades européias e, por último, o maior índice de alfabetização. Esse último fator teve uma enorme importância pelo fato de que as pessoas adquiriam mais informações através dos jornais, pelos quais eram estimuladas ao desejo de viajar. Com a melhora dos meios de transporte, a vida nas cidades e o trabalho em fábricas substituindo o trabalho doméstico, o turismo transformou-se em fenômeno mundial de massas.

A atividade turística apresentava-se mais organizada ao final do século XIX e no início do século XX. Conforme observamos em Oliveira (2001, p. 26), as férias dos trabalhadores, na Inglaterra, eram realizadas em acampamentos denominados holydays camps. Eles possuíam atividades programadas e todos os horários eram ocupados.

O governo inglês adotou, em 1915, o passaporte para controlar o grande fluxo de turistas por seu território. Ainda de acordo com Oliveira (ibidem), após a Primeira Guerra Mundial (1914/1918), o automóvel passou a ser o meio de transporte mais utilizado e mais popular da época. Famílias viajavam de forma econômica e segura por longas distâncias.

A depressão de 1930 e a Segunda Guerra Mundial (1939/1945) ocasionaram uma parada na evolução do turismo, pois a situação econômica não permitia gastos com supérfluos. Essa foi a época do ápice dos balneários ${ }^{7}$. Após o término da guerra, surgiu uma

\footnotetext{
${ }^{6}$ Tudo incluso (Home page Alta Vista, http://babelfish.altavista.com/babel fish/tr., acesso em: 15 jan. 2004)

${ }^{7}$ Mendonça et al., Home Page Estudos Turísticos, http://www.estudosturisticos.com.br/, acesso em: 05 mar. 2004
} 
grande novidade que revigorou a prática do turismo: a utilização do avião como meio de transporte de civis.

Oliveira (2001, p. 27) afirma que, em 1945, companhias comerciais criaram a primeira associação para a regulamentação do transporte aéreo, denominada IATA (International Air of Transport Association) ${ }^{8}$. O primeiro pacote de turismo que utilizou o avião como meio de transporte foi vendido em 1949. A partir de 1957, o avião passou a concorrer fortemente com os navios, pois exigiam menos tempo nos deslocamentos e oferecia preços mais acessíveis.

Voltando a Mendonça et al. ${ }^{9}$, os serviços oferecidos nesse período eram hotéis, operadoras de transportes, agências de viagem e operadoras de turismo. Segundo a mesma autora:

\begin{abstract}
Aliados às novidades tecnológicas nos transportes, surgiram os meios de comunicação que, com a divulgação dos atrativos turísticos via televisão, por exemplo, fizeram com que o turismo se expandisse rapidamente, principalmente nos países ricos, cujos habitantes se interessaram e começaram a viajar mais e preferencialmente em aviões. A mídia proporcionou aos turistas imagens que permitiram a eles selecionar e avaliar os lugares potenciais para visita. As classes mais baixas da sociedade passaram também a se interessar pelo turismo e demandaram outras modalidades, como o turismo desportivo e campings. Instituições especializadas, em resposta a esta demanda, se desenvolveram e passaram a prestar estes serviços. Em decorrência da percepção da divisão dessas duas classes, teve início o que se chama, hoje, de segmentação do mercado turístico.
\end{abstract}

Para Oliveira (2001, p. 25) o desenvolvimento tecnológico permitiu que, a partir de 1980, os serviços turísticos, englobando todas as áreas da atividade, passassem a

\footnotetext{
${ }^{8}$ Associação do Transporte Aéreo Internacional. (Souza e Correa, 2000, p. 81)

${ }^{9}$ Home Page Estudos Turísticos, http://www.estudosturisticos.com.br/, acesso em: 05 mar. 2004
} 
ser mais rápidos, eficientes e com preços mais baixos. Consumidores de viagens passaram a dispor de muitas das informações de que necessitavam em seus computadores domésticos.

Ainda segundo Oliveira (ibidem), com a globalização, o mundo ficou "menor” e as pessoas mais próximas umas das outras. Fronteiras, antes fechadas, abriram-se, permitindo a entrada dos turistas. O perfil do cliente mudou, fazendo com que as ofertas turísticas e os locais receptivos se vissem na obrigação de se adaptarem à nova realidade. $\mathrm{O}$ autor ilustra citando o caso de Cancun, no Caribe - México, como o maior e mais moderno centro turístico do mundo, totalmente planejado e projetado através do computador.

No século XX o turismo passou a integrar a vida das nações. Nessa fase percebe-se que as pessoas têm características e gostos diferentes. Realizam-se viagens de um lugar ao outro por diversas razões como eventos, esportes, religião, saúde, educação, entre outros.

Atualmente, com a constante necessidade de mudanças e a forte exigência do público, os empresários de turismo vêem-se obrigados a aperfeiçoar os serviços prestados e a mudar suas atitudes para um melhor atendimento a esse novo tipo de consumidor.

\section{2. Turismo: Conceitos e Definições}

Definir com precisão o turismo é uma tarefa que põe em choque vários autores pela quantidade de aspectos a serem envolvidos, tornando difícil reuni-los em um mesmo conceito. É, portanto, necessária, conforme Oliveira (2001, p. 33), a distinção entre o ato de fazer turismo e o de explorar o turismo, ou seja, sendo ele um modo de vida ou um meio de vida para melhor conceituação do fenômeno turístico.

Ferreira (1999, p. 2018) coloca que a palavra turismo quer dizer: viagem ou excursão feita por prazer a locais que despertem algum tipo de interesse; conjunto de serviços necessários para atrair aqueles que fazem turismo e dispensar-lhes atendimentos através de itinerários, guias, acomodações, transporte, entre outras formas de serviços. 
Voltando a Oliveira (ibidem, p. 35), no final do século XIX e início do século $\mathrm{XX}$, apareceu um grande número de conceitos que visavam o fenômeno turístico. No entanto, “quase todos perderam sua validade pela fraqueza de fundamentação ou pela falta de atribuição de autoria respeitável.”. Ele conceitua o mesmo, como sendo “um conjunto de resultados de caráter econômico, financeiro, político, social e cultural, produzidos em uma localidade, decorrentes da presença temporária de pessoas que se deslocam de seu local habitual de residência para outros, de forma espontânea e sem fins lucrativos.”.

Oliveira (ibidem) afirma que Herman von Schullard, em 1910, é o autor da mais antiga das conceituações do turismo ainda utilizadas. Para ele o turismo é "a soma das operações, especialmente as de natureza econômica, diretamente relacionadas com a entrada, permanência e o deslocamento de estrangeiros para dentro e para fora de um país, cidade ou região.”.

Para Leiper apud Cooper (2001, p. 40), o turismo pode ser pensado como “uma ampla gama de indivíduos, empresas, organizações e lugares, que se combinam de alguma forma para proporcionar uma experiência de viagem”. Em outras palavras, ela trata o turismo como uma atividade multidimensional e multifacetata, que tem contato com uma série de atividades econômicas e com muitas vidas diferentes.

Hunziker e Krapf apud Lickorish e Jenkins (2000, p. 50), professores suíços, publicaram em 1942 sua teoria geral sobre o turismo: "soma de fenômenos e relacionamentos que surgem das viagens e de estadas de indivíduos não-residentes, na medida que não visam a uma residência permanente e não são ligados a atividades remuneradas.”.

A definição de turismo aceita do ponto de vista formal é a fornecida pela Organização Mundial do Turismo - OMT apud Oliveira (2001, p. 35), que o define como “o fenômeno que ocorre quando um ou mais indivíduos se trasladam a um ou mais locais diferentes de sua residência habitual por um período maior que 24 horas e menor que 180 dias, sem participar dos mercados de trabalho e capital dos locais visitados.”. 
Para Ferreira (1999, p. 2018), turista é a pessoa que faz o turismo. Turístico é colocado em relação ao turismo ou aos turistas; lugar destinado principalmente ao turismo e que atrai ou interessa aos turistas.

Conforme Oliveira (2001, p. 37), “o termo visitante designa a pessoa que visita um local diferente de sua residência, sem intenção de exercer ocupação remunerada e cuja permanência não deve ser maior do que um ano.”.

De acordo com Lickorish e Jenkins (2000, p. 50), a União Internacional de Organismos Oficiais de Turismo - IUOTO, recomendou que o termo “visitante” deveria ser dividido em duas categorias: "turistas", englobando todos os visitantes que passem no mínimo uma noite no país ou local visitado; e "excursionistas” ou visitantes de um dia. Para a IUOTO o turismo pode apresentar-se sob três formas em um dado país:

- Turismo doméstico: é o ato de os residentes de um dado país que viajam apenas dentro do mesmo.

- Turismo receptivo: pessoas não-residentes que chegam para visitar um dado país.

- Turismo exportativo: pessoas que viajam para visitar um outro país.

Conforme Oliveira (2001, p. 74), a definição do tipo de turismo é importante para que cada localidade defina em qual deles suas características se enquadram, de acordo com o potencial da região. Essa definição também é relevante porque além de passar aos visitantes informações sobre os tipos de turismo que o local oferece, é ainda uma peça fundamental para orientar os que desejam investir no setor.

Os tipos de turismo existem também por causa das diversas motivações que levam o indivíduo a optar por um determinado destino de acordo com a sua educação, cultura, poder aquisitivo e faixa etária. Eles são divididos em (ibidem): 
- Turismo de lazer: praticado por quem viaja por prazer e deseja conhecer novos locais. Normalmente, esse turista viaja de carro com a família ou em excursões organizadas por agências de viagens. Ele exige boa infra-estrutura.

- Turismo de eventos: tem por público alvo pessoas que desejam participar de acontecimentos promovidos com o objetivo de discutir assuntos de interesses comuns ou para expor ou lançar novos artigos no mercado. Divide-se em regional, nacional e internacional.

- Turismo de águas termais: é um tipo de turismo sofisticado e localizado. Praticado por quem busca, nas estâncias hidrominerais, tratamentos de saúde ou simplesmente recreação.

- Turismo desportivo: praticado por pessoas que vão assistir ou participar de eventos desportivos. É o tipo de turismo que movimenta a economia local. Não só com a presença dos atletas e da assistência, mas também com as obras construídas exclusivamente em razão dos eventos. O público que pratica esse turismo é muito exigente.

- Turismo religioso: pessoas interessadas em visitar e conhecer locais sagrados. Motivado, em muitas ocasiões, pela fé ou necessidade de cultura religiosa, seja através de peregrinações, romarias ou congressos eucarísticos; seja através de visitação a igrejas e santuários.

- Turismo de juventude: praticado por jovens e estudantes que viajam, em geral, para comemorar o término dos cursos escolares. Seu público tem um perfil alegre, pouco exigente e com média capacidade de consumo. Em geral, é atraído por lugares que oferecem diversos divertimentos noturnos.

- Turismo social: é aquele praticado e fomentado com o objetivo de facilitar o turismo interno das classes economicamente menos favorecidas, principalmente operários. Eles 
contam com a ajuda das fábricas em que trabalham. Esse tipo de turismo é realizado geralmente em fins de semana, em destinos que sofrem com a sazonalidade, em épocas de baixa temporada, quando os preços dos hotéis caem consideravelmente e em locais não muitos distantes da residência habitual dos praticantes.

- Turismo cultural: praticado para satisfazer o desejo de emoções artísticas e informações culturais, visando à visitação a monumentos históricos, obras de arte, relíquias, antigüidades, concertos, musicais, museus e pinacotecas. Esse tipo de turismo tem um público muito específico. A atração cultural passa a ser a única motivação para visitar um lugar.

- Turismo ecológico: é uma forma responsável de viajar em áreas naturais, conservando o meio ambiente e o bem dos autóctones. Esses visitantes têm por objetivo respirar ar puro, apreciar a beleza do ambiente e registrar, em fotos e filmes, os elementos da flora e de fauna.

- Turismo de compra: turistas que têm como objetivo principal a compra. Vão em busca de centros turísticos que ofereçam qualidade, variedade e preços.

- Turismo de aventura: turismo que pressupõe uma programação com atividades participativas onde o turista passa a ser protagonista. Ele exige instalações, equipamentos, serviços auxiliares e guias especializados.

- Turismo gastronômico: são pessoas que viajam em busca da culinária da região visitada, seja apenas para se deliciar, seja para conhecer métodos de fabricação das comidas e bebidas.

- Turismo de incentivo: turismo resultante da política das empresas que querem aumentar a motivação de seus funcionários, oferecendo assim, viagens com direito a acompanhantes com tudo pago como premiação dos objetivos ou metas alcançados. 
- Turismo de terceira idade: é aquele destinado à melhoria da qualidade de vida da terceira idade e a diminuição dos efeitos da sazonalidade do turismo, desenvolvendo roteiros, programas e atrativos para a maior idade e incentivando a criação de clubes. Esse tipo de turista é atraído por locais seguros, com belas paisagens e que não exijam muito esforço físico.

- Turismo rural: turismo praticado em áreas rurais com o objetivo de proporcionar aos visitantes a oportunidade de participar das atividades próprias da zona rural, como: andar de cavalo, ordenhar vacas, caminhar pelos campos etc.

- Turismo de intercâmbio: tem o objetivo de realizar cursos ou aprender idiomas em outros países. Normalmente é praticado por jovens.

- Turismo de cruzeiros marítimos: o objetivo é conhecer diversos lugares com um excelente tratamento de bordo.

- Turismo de negócios: praticado por executivos que viajam para participar de reuniões, visitar fornecedores ou fechar negócios. Trata-se de um público exigente, que se hospeda em hotéis de luxo que disponham de serviços especializados.

- Turismo técnico: praticado por pessoas que trabalham em áreas técnicas e que necessitam conhecer as instalações de seus fornecedores ou resolver determinados problemas nas mesmas.

- Turismo gay: consiste em um turismo voltado para o público homossexual. Por serem, em sua maioria, solteiros, sem filhos e pertencerem às classes econômicas A e B, esse segmento tem condições de gastar mais em viagens. É um público extremamente exigente quanto aos serviços. (Ansarah, 1999, p. 182)

- Turismo de saúde: praticado por pessoas que necessitam realizar tratamentos de saúde. 
- Turismo étnico e nostálgico: o atrativo turístico é visitar os lugares de origem ou dos antepassados dos turistas praticantes dessa atividade.

Para Barreto (1995, p. 33), atrativo turístico é aquilo que atrai o turista do ponto de vista do núcleo. É o recurso. Portanto atrativo e recurso são sinônimos. Cabe ressaltar que atrativo turístico é todo lugar, objeto ou acontecimento que possam despertar algum tipo de interesse no turista. É o componente principal do produto turístico, pois determina a seleção, por parte do turista, do local a ser visitado, gerando uma corrente turística até o destino.

Diversos autores têm realizado diferentes classificações para os atrativos turísticos, com a intenção de facilitar a análise dos mesmos. Cabe destacar a seguinte classificação de Swarbrooke apud Sanchos (2001, p. 122):

- Atrativos naturais: praias, grutas, montanhas, rios, lagos, bosques, flora, fauna, etc.

- Atrativos criados pelo homem, mas não planejados com a intenção de atrair visitantes: catedrais, igrejas, casas históricas, monumentos, jardins históricos, etc.

- Atrações criadas pelo homem, planejadas com a intenção de atrair visitantes: parque de diversões, parques temáticos, museus, centros de exibições, cassinos, centros de lazer, balneários, lugares para piqueniques, etc.

- Eventos especiais: festivais de arte, encontros esportivos, mercados e feiras, folclore, aniversários históricos, eventos religiosos, etc.

Por outro lado, Gunn apud Sanchos (2001, p. 121), não podemos confundir atrativo com recurso. Os recursos são as formas originais, a matéria-prima dos futuros atrativos turísticos. Dessa maneira, podem-se oferecer praias, montanhas ou a história de um dado país, quando esses estão situados em lugares acessíveis e válidos para exploração turística, criando-se uma infra-estrutura adequada para transformá-los em atrativos turísticos. 
Infra-estrutura é a base material; o conjunto de edificações, obras e serviços públicos que garantem o mínimo de conforto na vida atual. Barretto (1995, p. 39) afirma que a infra-estrutura turística é constituída pela soma de:

- Infra-estrutura de acesso (estradas, aeroportos, portos, rodoviárias, estações de trem);

- Infra-estrutura básica urbana (ruas, sarjetas, iluminação pública etc.);

- Equipamentos turísticos, que são as construções que permitem a prestação dos serviços turísticos (alojamentos, nos núcleos receptores; agências, nos núcleos emissores; transportadoras entre ambos);

- Equipamentos de apoio, que são instalações que permitem a prestação de serviços que não são exclusivamente turísticos, mas são quase indispensáveis para o desenvolvimento desta atividade (rede de atenção médico-hospitalar, rede de atenção ao automóvel, rede de entretenimento etc.).

A rede gastronômica (conjunto de restaurantes, lanchonetes e similares com oferta alimentar) pode ser um equipamento turístico ou um equipamento de apoio, dependendo de sua posição no núcleo. Se é a única oferta alimentar do local, será um equipamento turístico. Se atende turistas esporadicamente, será um equipamento de apoio.

Como último conceito temos que produto turístico, segundo Medlik e Midleton apud Ruschmann (1990, p. 26), é o conjunto de atrações do núcleo receptor: as facilidades oferecidas aos turistas, as vias e os meios de acesso. É a soma de elementos tangíveis e intangíveis, centralizados numa atividade específica e numa determinada destinação, das quais o turista compra a combinação das atividades e arranjos.

\section{3. Importância Social e Econômica do Turismo}

A função básica do turismo é a ocupação do tempo livre dos turistas. De acordo com Oliveira (2001, p. 41), o homem sempre buscou uma situação sócio-econômica que lhe 
permitisse uma vida confortável, tranqüila e com mais horas livres. A criação de sistemas operacionais e administrativos capazes de reduzir o tempo de trabalho e ampliar as horas dedicadas ao lazer, fruto do esforço humano ao longo dos séculos, já é uma realidade em muitos países de primeiro mundo. Os países de terceiro mundo ainda dão seus primeiros passos nesse sentido.

A nossa civilização foi descrita corretamente por alguns sociólogos como sendo a civilização do ócio. Nos países industrialmente avançados, as semanas de trabalho foram reduzidas para 40 horas e as perspectivas já justificam as otimistas previsões de Jean Fourastié, segundo as quais por volta de 1995 a semana de 30 horas seria uma realidade...

(Wahab apud Oliveira, 2001, p. 41)

O aumento das horas livres, com a redução dos custos nos transportes e a globalização, tornou os povos mais próximos, dando ao homem atual mais informações sobre as atrações turísticas mundiais. O turismo cumpre sua função básica de transformar o tempo livre em lazer.

Oliveira (2001, p. 44) afirma que o turismo, na economia mundial, vem gerando fenômenos de consumo, originando rendas, criando mercados nos quais a oferta e a procura encontram-se. O resultado, a olhos vistos, é um grande e expressivo movimento financeiro, justificando a inclusão da atividade na programação da política econômica de todos os países. A atividade que, para muitos, era considerada secundária, passou a receber atenção especial em virtude de ser uma fonte criadora de receitas e a exigir metódica e delicada manipulação, consolidando-se dentro do conceito de “indústria normal”.

Segundo Sanchos (2001, p. 10), a indústria do turismo distingue-se por sua grande complexidade, não apenas pela quantidade de elementos de que é composta, mas também pelos diferentes setores econômicos de seu desenvolvimento.

Sendo assim, o turismo é notado como um fator de exportação de uma localidade de destino (país receptor, local de recebimento, no qual gera renda, favorece a 
entrada de divisas - que ajudam a equilibrar a balança de pagamentos, utiliza os bens da natureza sem agredi-los, cria empregos, aumenta os impostos públicos e aquece as atividades empresariais) até uma determinada região ou nação (de onde vêm os turistas).

O desenvolvimento do turismo em uma determinada região leva o Poder Público a adaptar seus esforços às novas necessidades da localidade. Há o aumento no abastecimento de água e luz, problemas de saneamento básico são resolvidos, estradas recebem pavimentação, os terminais aéreos e rodoviários são modernizados, além da valorização cultural do local pela comunidade autóctone e o aumento no nível de educação da comunidade.

A importância do turismo difere por regiões, uma vez que o seu grau de desenvolvimento segue um ritmo de crescimento muito particular em cada localidade. Esse fato fundamenta-se na incidência de um ou mais dos seguintes fatores (Secretária Geral de Turismo apud Sanchos, 2001, p. 15): “grau de desenvolvimento e crescimento econômico; renda disponível da população; tempo livre; aspectos demográficos (diferenças na média de idade, na quantidade, etc); entorno político; costumes e crenças; nível de educação e; grau de desenvolvimento tecnológico.”.

Quanto maior o índice de desenvolvimento econômico da região, maior sua capacidade tecnológica, renda disponível, nível de educação e tempo livre. Todos esses fatores colaboram coma o crescimento do turismo. Verifica-se, dessa maneira, a interrelação desses fatores.

A América esteve situada, de 1985 a 1995, de acordo com a Organização Mundial do Turismo - $\mathrm{OMT}^{10}$, em segundo lugar no "ranking” de recebimentos de turistas internacionais (excluídos visitantes de um dia). A América do Sul registrou um crescimento de turistas europeus e norte-americanos no mesmo período.

\footnotetext{
${ }^{10}$ Home Page da EMBRATUR, http://www.embratur.gov.br/0-catalogo-documento/evolucao/evolucaodoturis monobrasil19922002.pdf, acesso em: 11jan. 2004
} 
Segundo dados divulgados pelo Instituto Brasileiro de Turismo EMBRATUR $^{11}$, através da coletânea Evolução do Turismo no Brasil 1992 -2002, o turismo gerou no Brasil:

- US\$ 3,1 bilhões de receita cambial - 2002;

- chegada de 3,8 milhões de turistas estrangeiros - 2002;

- 27, 94\% das chegadas de turistas na América do Sul e 0,53\% em nível mundial - 2002;

- a geração de 4. 886. 378 empregos nas atividades turísticas - 2001;

- R\$ 73 milhões de investimentos no apoio à melhoria e à implantação da infra-estrutura turística - 2001;

- 41 milhões de turista domésticos - 2001;

Desta forma, conforme Oliveira (2001, p. 49), o turismo prova ser uma das mais dinâmicas fontes de emprego e divisas, quer em países em desenvolvimento, quer nas nações desenvolvidas.

\footnotetext{
${ }^{11}$ Home Page da EMBRATUR, http://www.embratur.gov.br/0-catalogo-documentos/evolucao/Evolucaodotu rismonoBrasil 19922002.pdf, acesso em: 11 jan. 2004
} 


\section{Terceira Idade}

Com base nas definições sociais que variam conforme a época, cultura e o lugar analisado percebem-se as modificações no tratamento dispensado aos velhos através dos anos. Ao longo da história do ser humano, colocaram-se dois problemas básicos a respeito da velhice: vantagens e inconvenientes inerentes à mesma e como impedir o processo de envelhecimento.

De acordo com Lorda e Sanchez (1998, p. 03), o estudo da visão que a sociedade possui dos idosos remonta aos tempos dos babilônios, dos hebreus e da antiga Grécia. Nas sociedades primitivas a longevidade vinculava-se à sabedoria e experiência, sempre associada ao sagrado. Nessa época, alguns povos acreditavam na reencarnação após a morte, em que o espírito ocupava o corpo de outra pessoa. Essa crença ocasionou a morte de muitas pessoas antes que sofressem os declínios da velhice.

A civilização Egípcia, segundo Mazo (2001, p. 26), deixou poucos testemunhos sobre a velhice, mas sabe-se que no Egito antigo, as elites tinham consciência do valor da experiência e sabedoria dos anciãos. O Judaísmo venerava as pessoas idosas, bem como a figura do patriarca e a paternidade em idade avançada.

Lorda e Sanchez (1998, p. 05) relatam que a China, desde épocas remotas, considerava o ancião possuidor de condições privilegiadas. O objetivo supremo do homem era alcançar a vida longa. Já a Grécia clássica idealizava a beleza, a força e a juventude, relegando, desta maneira, aos velhos um lugar subalterno. Todavia era uma sociedade em que não transparecia haver desprezo aos velhos, a quem era atribuída a virtude da sabedoria.

Os idosos, na civilização romana, possuíam um papel essencial na tomada de decisões. O direito romano concedia uma autoridade particular aos anciãos na figura dos pater familia, sendo o chefe absoluto, exercendo poder sobre todos os membros da família. O resultado desse papel do idoso, nesse período, foi o início do conflito de gerações e do 
sentimento de ódio aos seniores. Com a evolução da história política romana, os velhos perderam o poder. Convertem-se em encarnação do sofrimento.

Segundo os mesmos autores (ibidem, p. 09), por ocasião do advento do Cristianismo, período em que a virtude e a sabedoria tinham elevada importância, a velhice correspondia à moral. Por outro lado, a decrepitude e a feiúra da velhice associavam-se à imagem do pecado, parte da dolorosa herança de Adão, que preferiu o sofrimento ao paraíso e a vida eterna. Santo Agostinho classificava a velhice como a última etapa que simbolizava o renascer da vida espiritual. Os muçulmanos, na Idade Média, possuíam uma idéia sobre a natureza da velhice muito similar à dos greco-romanos.

Para Mazo (2001, p.27), a Idade Média produziu uma mudança social e econômica, ou seja, o predomínio rural foi substituído pelo surgimento de conglomerados urbanos. Com o aumento da atividade comercial, nasce uma nova classe, que tem um forte ideal de trabalho e riqueza: a burguesia. Seu surgimento acarreta na mudança da situação dos idosos, pois o acúmulo de riquezas os torna poderosos.

Contudo, de acordo com Lorda e Sanchez (1998, p. 10), a Idade Média também caracterizou-se pela predomínio do mais forte, física e militarmente. Os mais débeis, entre eles os velhos, foram submetidos aos mais fortes, compondo a população escrava e serviçal.

Ainda conforme os autores supracitados, no século VI começa-se a identificação da velhice com o cessar da atividade, iniciando, assim, a concepção moderna de isolamento do ancião mediante o retiro. Os séculos XVI e XVII caracterizaram-se pelas novas formas de pensar. Achava-se que era possível descobrir as causas do envelhecimento através de um estudo sistemático.

Nos séculos XVIII e XIX (ibidem, p. 11), o aumento da expectativa de vida da população européia é um fato a se considerar, devido às melhores condições de higiene e de recursos materiais. Todavia, esse crescimento aparece nas classes privilegiadas, pois nas dos operários a longevidade não era possível devido ao fato deles serem dizimados pelo 
trabalho, e pela fadiga. Os velhos da classe operária eram reduzidos à miséria, já que a idade já não mais lhes permitia trabalhar.

Segundo Mazo (2001, p. 29), com o progresso da medicina, no século XIX, as pessoas passam a viver mais e surge uma maior preocupação por parte dos médicos, cientistas e pesquisadores em relação à velhice. Nesse período, há um considerável aumento no número de obras sobre o assunto.

De acordo com Fustinoni e Passnante apud Mazo (2001, p. 29), o século XX é denominado “O Século da Revolução Vital”, devido ao grande aumento da população idosa nos países em desenvolvimento e suas projeções para o século XXI.

Lorda e Sanchez (1998, p. 11) afirmam que a investigação científica sobre a velhice recebe grande impulso com o nascimento da Gerontologia, em 1903, e da Geriatria, em 1909. A Gerontologia é definida como o estudo científico do processo de envelhecimento e dos seus problemas especiais, abordando todos os aspectos fisiológicos, sociais e psicológicos da velhice. A Geriatria é a ciência médica que estuda e trata das enfermidades e mudanças da velhice.

\section{1. Origem dos Termos}

A origem das palavras ligadas ao envelhecimento, em grande parte da literatura existente sobre o referido assunto, não é comentada. Dada a importância de se diferenciarem os significados das palavras mais usuais para caracterizar o envelhecimento, utilizaram-se como recursos os conceitos etimológicos do Novo Aurélio Século XXI: o dicionário da língua portuguesa, de Ferreira (1999):

- Velho (p. 2054): palavra originada do latim velutu, através de uma forma hipotética vetlu, pronunciada veclu. Como adjetivo, quer dizer muito idoso; de época remota; 
antigo; que tem muito tempo de existência. Como substantivo tem o significado de homem idoso; pai; papai (familiar).

- Velhice (ibidem) tem as seguintes conotações: estado ou condição de velho; idade avançada; antigüidade; vetustez.

- Senil (p. 1837) equivale a senile do latim, que significa como adjetivo: da velhice, ou relativo a ela ou aos velhos; próprio da velhice; da senilidade.

- Senilidade (ibidem) traduz qualidade ou estado de senil; decrepitude; fraqueza intelectual resultante da velhice.

- Senescente (p. 1836) veio do latim senescente. Como adjetivo tem significado de que está envelhecendo.

- Senescência (ibidem): o substantivo origina-se do latim senescentia; qualidade ou estado de senescente.

- Idoso (p. 1073): por haplologia (ou redução) da palavra idadoso, que como adjetivo quer dizer: quem tem bastante idade, velho.

- Geronto (p. 985): originou-se do grego geront, geronto. Representa pessoa idosa,;sábia; digna de respeito.

- Ancião (p. 133): origem do francês antigo ancien, cujos sentidos como adjetivos são: diz-se de pessoa de idade provecta; velho, idoso; antigo; homem muito velho e respeitável.

- Decrépito (p. 611): igual a decrepitu do latim, expressa no adjetivo: muito idoso ou enfraquecido e desgastado fisicamente; por extensão, diz-se animal velhíssimo e fraco; diz-se de coisa muito deteriorada e em ruína. 
- Decrepitude (ibidem): significa estado ou condição de decrépito; velhice extrema; decadência física e/ou mental; decrepidez.

Costa, E. (1998, p.25), afirma que, segundo os significados mencionados, essas palavras poderiam ser consideradas sinônimas, entretanto, existem pequenas diferenças entre si que se fazem evidentes em alguns casos e, em outros, implicam arbitrariedade e confusão.

Entretanto, neste estudo, esses termos serão considerados sinônimos para uma melhor assimilação do seu tema principal: A Terceira Idade.

Mas, o que é a terceira idade? Para a correta resposta a essa pergunta é necessária a compreensão de uma outra pergunta: Quando se inicia o processo de envelhecimento?

De acordo com Araujo (2000, p.10), “não é possível estabelecer conceitos, definições e terminologia universalmente aceitáveis ou que se encaixem perfeitamente em situações, lugares e épocas distintas”. Dessa forma serão expostas algumas definições, conceitos e terminologias consideradas as mais importantes no estudo do envelhecimento humano.

Costa, E. (ibidem, p. 26), menciona também que, o envelhecimento, segundo muitos autores, é um ato contínuo, sem interrupção, que se inicia a partir do nascimento do indivíduo até o momento de sua morte. Nessa visão, o envelhecimento é a marcha natural pela qual todo ser humano passa, num processo constante de transformação.

Otto apud Mazo (2001, p. 51) define o envelhecimento através dos fatores psicológicos e sociais, onde coloca que o homem, à proporção que envelhece, perde papéis e funções sociais, o que acarreta o afastamento do convívio de seus semelhantes. Para Salgado (ibidem), o envelhecimento dá-se de forma diferenciada para cada indivíduo, 
conforme a maneira que cada um se vê. Embora o físico e a mente envelheçam juntos, o processo não se dá em ambos com o mesmo ritmo.

Na visão de Costa, E. (1998, p. 31), o processo de envelhecimento é estudado sob três óticas: cronológica, biológica e pessoal.

O conceito cronológico é adquirido pela subtração da data de nascimento da data atual, sendo a idade cronológica aquela que consta na certidão de nascimento, não podendo ser negada.

O conceito biológico é aquele estabelecido pelas condições da pessoa na escala molecular, em níveis de células e de tecidos; dos órgãos e suas funções; de personalidade e de grupos humanos, enfim, os fatores biopsicossociais de cada ser humano.

O conceito pessoal é aquele que a própria pessoa determina, ou seja, é a condição pessoal de ser ou estar velho, de se sentir com uma determinada idade, embora não seja a idade cronológica de fato. Torna-se mais forte do que os sintomas da velhice.

Segundo Rodrigues apud Mazo (2001, p. 52), as formas de classificação da velhice ou de representação que definem em que estágio de envelhecimento o indivíduo se encontra, são classificadas em: primeira idade (0 a 20 anos); segunda idade: (21 a 49 anos); terceira idade: (50 a 77 anos) e; quarta idade: (78 a 105 anos).

Ainda de acordo com a mesma autora, psicólogos dividem a maturidade em três etapas: maturidade inicial (20 a 40 anos); maturidade média (41 a 65 anos) e maturidade tardia (66 anos em diante). Dentro da maturidade tardia existiriam mais três tipos de idade cronológica que são: idoso jovem (66 a 74 anos); idoso velho (75 a 85 anos) e a manutenção pessoal (acima de 86 anos).

A Política Nacional do Idoso (1999, p. 69), em seu Capítulo I, Artigo 2ª Da Finalidade, “considera o idoso, a pessoa maior de sessenta anos de idade”. 
A Organização Mundial de Saúde - OMS apud Mazo (2001, p. 52) afirma que o idoso é "todo indivíduo com 65 anos de idade, ou mais, que reside em países desenvolvidos e com 60 anos, ou mais, os que residem em países em desenvolvimento". Nota-se que o conceito da OMS para idoso está ligado diretamente com a qualidade de vida propiciada pelo país aos seus cidadãos.

Através da resolução 39/129, a Organizações das Nações Unidas - ONU apud Costa, E. (1998, p. 31) definiu o ciclo de vida sob a visão econômica, ou seja, o homem considerado enquanto força de trabalho, produzindo e consumindo os bens produzidos. Essa classificação é dividida em três idades, a relatar:

- Primeira idade: (crianças e adolescentes) pessoas que só consomem idade improdutiva;

- Segunda idade: (jovens e adultos) pessoas que produzem e consomem - idade ativa;

- Terceira idade: (idosos) pessoas que já produziram e consumiram, mas que, pela aposentadoria, não produzem mais, só consomem - idade inativa.

Segundo Mazo (2001, p. 55), o termo “terceira idade” origina-se na França, associado às novas práticas de lazer, às férias e aos serviços especiais de saúde para os aposentados, nascendo assim a idéia de terceira idade que se difundiu em diferentes nomenclaturas de programas e projetos de instituições governamentais e nãogovernamentais. Foi empregado inicialmente no Brasil pelo SESC ${ }^{12}$ de São Paulo em 1977, na criação das “Escolas Abertas para Terceira Idade”. Para o mesmo autor:

Terceira Idade representa a velhice como uma nova etapa de vida, expressa pela prática de novas atividades sociais e culturais. A representação de estar na terceira idade está vinculada à nova imagem de envelhecimento, onde os indivíduos com idade avançada constroem novos

\footnotetext{
${ }^{12}$ Serviço Social do Comércio (Ferreira, 1999, p. 1846)
} 
significados, que favorecem a uma participação social, autovalorização, convívio com suas perdas e suas transformações.

Para Gaelzer (1985, p. 59), a terceira idade seria a idade na qual o ser humano passa a usufruir os direitos de não-trabalhar, sendo um período nobre da vida no qual o idoso, estando preparado para a liberdade de usar seus recursos pessoais, deve ser respeitado e ter assegurado na sociedade o seu espaço existencial e humano.

O termo "terceira idade”, conforme Chopra apud Mazo (2001, p. 56), foi o ponto de início para o surgimento de outros termos como “melhor idade”, originado através de uma pesquisa realizada em Baltimore - Estados Unidos da América, em 1985, pela qual constatou-se que, com a idade, as pessoas adquirem características únicas e, nesta individualidade, inclui-se a possibilidade de melhoria em qualquer setor. Desta maneira, o corpo e a mente não possuem idades cronológicas, resultando em uma nova concepção de envelhecimento.

Mazo (2001, p.56) destaca que outros termos como "idade feliz", "maior idade”, “boa idade”, “idade dourada”, reafirmam a relação com "melhor idade”, pois destacam ganhos adquiridos na velhice. Além do termo “terceira idade”, na França o uso do termo "quarta idade” já é bastante comum para denominar os idosos, acima de 75 anos de idade.

\section{2. Aspectos Biopsicossociais da Velhice}

Envelhecer impõe ao indivíduo desgastes em suas capacidades fisiológicas globais, seja de um modo progressivo, discreto ou grave. Ocorrem, também, mudanças psicossociais em relação à memória, ao intelecto, ao comportamento, à personalidade, às relações sócio-familiares, às finanças, dentre outros.

Neste capítulo, serão expostas as mudanças dos aspectos biológico, psicológico e social no processo de envelhecimento humano de acordo com Mazo (2001, p. 58-69): 
a) Aspecto Biológico

O processo biológico revela-se por um declínio harmônico de todo o conjunto orgânico, tornando-se mais acelerado a partir dos 70 anos de idade. As principais alterações que podem ocorrer em cada sistema são:

- Imunológico - a partir do processo de envelhecimento, as respostas imunológicas tornam-se menos eficientes pela redução do seu ritmo;

- Cardiovascular

- aumento da fase de ejeção sangüínea;

- diminuição do débito cardíaco;

- diminuição da freqüência cardíaca máxima;

- Endócrino

- redução da capacidade de recuperação de queimaduras, feridas e traumas cirúrgicos;

- redução da capacidade de respostas aos estresses do calor e frio;

- redução da capacidade de manter o nível normal de glicose no sangue (aumentando sua quantidade de açúcar).

- Reprodutor Feminino

- diminuição da produção de óvulos normais;

- defeitos cromossômicos são mais comuns em óvulos de mulheres no climatério, na prémenopausa;

- redução dos níveis de hormônios circulares com a menopausa (estradiol, progesterona e testosterona);

- redução do peso e tamanho do útero;

- redução da vagina em tamanho e diâmetro, bem como, secreções das glândulas locais;

- $\quad$ as mamas tornam-se flácidas; 
- Reprodutor Masculino

- redução na produção hormonal que regula a função reprodutiva;

- diminuição da libido e da capacidade sexual;

- aumento da próstata;

- diminuição da variedade de fluidos durante a ejaculação;

- Músculo-Esquelético

- redução do número de células musculares e da elasticidade dos tecidos;

- substituição do tecido muscular por colágeno;

- diminuição da massa óssea (aos 50 anos as mulheres perdem em torno de 30\% e os homens em torno de 17\%);

- alterações posturais (as costas tendem a ficar arqueadas, curvadas e corcundas - cifose);

- redução na mobilidade articular.

- Nervoso

- diminuição do cérebro em torno de 20\% de seu peso, comparando um indivíduo de 20 a um de 90 anos de idade;

- diminuição das substâncias químicas associadas à atividade neurotransmissora;

- diminuição de receptores cutâneos, reduzindo a percepção da temperatura ambiente e da sensibilidade tátil.

- Respiratório - insuficiência respiratória restritiva, obstrutiva e disfuncional, notadas, principalmente, quando o idoso realiza algum esforço.

- Gastrointestinal

- perdas e alterações involuntivas dos dentes;

- diminuição da produção de enzimas e sucos gástricos;

- diminuição da mobilidade do peristaltismo (constipação);

- atrofia da mucosa gástrica;

- diminuição da capacidade de absorção de nutrientes; 
- diminuição do volume e peso do fígado (como resultado destas alterações, observa-se a diminuição do metabolismo de algumas drogas que passam primeiramente pelo fígado).

- Função Renal

- redução do tamanho e peso dos rins;

- alterações tubulares;

- Alterações Nucleares, Citoplasmáticas e Teciduais - esses eventos estão ligados com a aparência física:

- estatura: diminui com a idade, se inicia nos homens a partir dos 43 anos de idade, podendo ser observada em alguns casos aos 60 anos. Supõe-se que isso ocorra devido à perda de água, enfraquecimento de grupos musculares, mudanças posturais, osteoporose, deterioração dos discos espinhais e deformidades espinhais;

- peso: aumenta na meia idade e diminui na velhice. Essa alteração é atribuída à diminuição dos órgãos e da massa celular;

- rosto: as orelhas e nariz se alongam;

- pele: fica enrugada, ressecada, aumenta a pigmentação amarelada, há aparecimento de calosidades, o odor corporal e a capacidade de cicatrização diminuem;

- unhas: dos 30 aos 90 anos de idade, diminui o crescimento em até 50\%;

- cabelos e pêlos: tornam-se grisalhos, com menor densidade, força e diâmetro. O crescimento é menor e a perda maior;

- audição, paladar, olfato e visão diminuem com o processo de envelhecimento;

- sono: os indivíduos idosos têm menos sono, sendo maior o número de vezes que acordam durante a noite: mais comum nos homens. Os distúrbios respiratórios e a freqüência do ronco aumentam;

- água corporal: há diminuição com a idade.

Algumas dificuldades relacionadas com a eficiência motora são visíveis nos idosos, tais como: subir escadas, caminhar e realizar certos movimentos com lentidão. É o resultado da diminuição gradativa da velocidade, força, resistência, coordenação e flexibilidade. 
b) Aspecto Psicológico

Ao longo dos anos as circunstâncias do cotidiano modificam-se, resultando na tomada de novos papéis e o aparecimento de novos problemas a enfrentar, de modo a ocorrerem alterações psicológicas em cada indivíduo. A adaptação a essas alterações podem ser mais rígidas ou menos rígidas conforme os fatores individuais ocorridos em épocas anteriores de sua vida.

Diversas tendências são apontadas por estudiosos da área com relação às modificações psicológicas ocorridas durante a velhice:

- O entusiasmo e a motivação tendem a diminuir, sendo necessário um maior estímulo do idoso para lhe fazer compreender novas situações ou ações;

- Maior apego a seus pertences e à sua conservação fazendo com que o idoso tenha necessidade de viver em um ambiente estável, sem mudanças súbitas;

- Preocupação com a diminuição da vitalidade mental e física;

- Perda da intensa convivência com a sociedade;

- Maior seletividade dos relacionamentos afetivos e sociais, sendo os familiares o maior foco de atenção;

- Maior percepção da incapacidade para realização de novos relacionamentos e novas atividades;

- Sentimentos de isolamento e solidão;

- Aumento do número de óbitos de parentes e amigos queridos; 
- Maior freqüência de retorno ao passado;

- Vida contemplativa, sem significar somente a depressão;

- Expansão da espiritualidade e religiosidade;

- Redefinição da vida conjugal e sexual;

- Aumento da necessidade de ser cuidado e de cuidar do outro;

- Maior tolerância à rotina, mesmo com o decréscimo físico;

- Rigidez, egocentrismo, desconfiança, irritabilidade e avareza;

- Maior apego a valores já conhecidos e convencionados;

- Dificuldade em se aceitar como alguém que está envelhecendo.

É importante ressaltar que os idosos, devido aos declínios do organismo, dão preferência a atividades que requeiram menor esforço, apresentando grande interesse àquelas que são praticadas em grupo, em contato com outras pessoas.

De acordo com Costa, E. (1998,p. 50), esses perfis devem conter elasticidade, pois traçar o perfil do velho psicologicamente típico, é impossível. Dado o fato de que o comportamento na senectude é igual ao de outras idades, dependendo das motivações do senescente e os significados pessoais inscritos às situações.

c) Aspecto Social

Segundo Kane apud Mazo (2001, p. 65), várias dimensões podem ser avaliadas ou observadas no posicionamento social do ancião, tais como: as relações sociais 
(freqüência, contexto e qualidade); as atividades sociais (freqüência, natureza e qualidade); os recursos sociais (rendimentos, moradia e condições ambientais); o suporte social da família; as violências praticadas contra o idoso; as manifestações sexuais; a religiosidade e a espiritualidade.

Em uma sociedade na qual a força da produção tem elevada importância e o homem é julgado por sua capacidade de produzir, a valorização do potencial da juventude em detrimento do idoso traz problemas àqueles que têm idade avançada.

Com a chegada da aposentadoria, a vida das pessoas mais velhas sofre uma grande mudança quanto às atividades e às relações sociais. $\mathrm{O}$ momento em que o indivíduo se afasta de sua atividade profissional pode acarretar um processo de despersonalização e marginalização social. A falta de ocupação gera um sentimento de inutilidade, de exclusão como membro produtivo e útil de seu grupo social. Para algumas pessoas a aposentadoria é considerada como um marco no processo de envelhecimento.

Ao abandonar o convívio social do ambiente de trabalho, o idoso tende a conviver, com maior freqüência, com os familiares mais próximos. Os relacionamentos familiares diferenciam-se na forma e significação em cada sociedade de acordo com o seu período histórico, em função do seu contexto cultural, social e econômico. Apesar dessas variações, a família é o refúgio onde o idoso procura cuidados, proteção, afetividade, socialização e formação de personalidades, sendo a função universal da família a preservação da espécie.

Com relação ao idoso, a função de proteção é caracterizada como uma das mais importantes, sendo a família uma rede de suporte necessária para o ancião, independentemente das tradições culturais e econômicas de cada sociedade, pois ela ainda é a principal responsável pela manutenção e cuidado de seus idosos. Todavia, muitas vezes é observado o uso de violência contra o idoso no meio familiar, ocasionado por membro da própria família encarregado dos seus cuidados. 
A sexualidade do ancião é estereotipada num envelhecimento sem sexo, gerando preconceitos ao se tratar de sexo na velhice. O ambiente e a falta de oportunidade desestimulam o idoso para o sexo. Na família, os filhos negam a sexualidade dos pais, e quando a admitem tratam-na como algo depreciativo. Nas instituições asilares, a estrutura e o regulamento não permitem a expressão da sexualidade em suas diferentes formas, e principalmente, no que se refere a relações sexuais.

Apesar desses fatos é importante observar que a sexualidade do idoso está ligada àquela ao longo de sua vida. As pessoas que tiveram uma prática sexual intensa tendem a continuar mais ativas na velhice. A existência de um parceiro fixo configura-se no incentivo à prática sexual. O grau de preconceito e o conservadorismo de cada idoso irá determinar uma vida mais ou menos aberta à atividade sexual durante a velhice.

A espiritualidade e a religiosidade na velhice é mais evidenciada, tornando-se ponto de apoio para o encontro espiritual e existencial que dá sentido à vida. Muitas vezes são associadas ao bem-estar psicológico e à necessidade de manter um certo controle sobre a morte.

\section{3. Estatísticas do Aumento do Envelhecimento da População no Mundo e no Brasil}

Becker apud Araújo (2000, p. 12), aponta que a principal herança do século XX foi o aumento da expectativa de vida e atribui esse fato aos avanços no campo da saúde ocorridos a partir de 1900, ou seja, à medida que as sociedades desenvolvem, cresce também a idade de suas populações.

Bento (1999, p.14) justifica que o aumento da expectativa de vida do idoso e o envelhecimento da população estão acontecendo por duas razões essenciais: os índices de natalidade estão diminuindo e a longevidade está crescendo tão aceleradamente a ponto de encolher os índices de mortalidade. 
A afirmação desta questão se dá através das análises demográficas realizadas pela Organizações das Nações Unidas - ONU apud Araujo (2000, p. 03). Elas indicam que as pessoas com sessenta anos ou mais atingirão, em 2050, o número de aproximadamente dois bilhões.

De acordo com as pesquisas do Instituto Brasileiro de Geografia e Estatítica IBGE apud Araujo (ibidem), nas últimas décadas o número de pessoas com sessenta anos ou mais aumentou consideravelmente nos países da América Latina, principalmente em Cuba, Argentina, Uruguai, Chile, e Brasil. Esses dados evidenciam que o envelhecimento da população na América Latina também está seguindo a tendência mundial.

A Tabela 01, demonstra com maior clareza a estimativa do processo de envelhecimento da população brasileira em relação a outros países de 1996 a 2025. Na maioria dos países analisados observa-se que o índice de idosos em sua população irá duplicar.

TABELA 01: População e a estimativa de idosos do Brasil em relação a outros países de 1996 a 2025.

\begin{tabular}{|l|c|c|c|c|c|}
\hline \multicolumn{1}{|c|}{ País } & $\begin{array}{c}\text { Posição em } \\
\mathbf{1 9 9 6}\end{array}$ & $\begin{array}{c}\text { Número } \\
\text { Absoluto }\end{array}$ & $\begin{array}{c}\text { Posição em } \\
\mathbf{2 0 2 5}\end{array}$ & $\begin{array}{c}\text { Número } \\
\text { Absoluto }\end{array}$ & Aumento \% \\
\hline China & 1 & 115,2 & 1 & 290,6 & 152,3 \\
\hline Índia & 2 & 61,9 & 2 & 165,1 & 166,7 \\
\hline USA & 3 & 43,9 & 3 & 82,5 & 87,9 \\
\hline Japão & 4 & 26,3 & 4 & 39,6 & 50,6 \\
\hline Indonésia & 6 & 13,0 & 5 & 37,8 & 190,8 \\
\hline Rússia & 5 & 24,7 & 6 & 34,2 & 38,5 \\
\hline Brasil & 11 & 11,6 & 7 & 30,7 & 164,7 \\
\hline
\end{tabular}

Fonte: CHAIMOWICZ Apud MAZO, 2001, p. 16. Número absoluto = milhões de idosos. 
No ano 2025, dos 11 países que terão as maiores populações de idosos em número absoluto (todas acima de 16 milhões), serão, em sua maioria, do Terceiro Mundo. O Brasil será o sétimo país em números absolutos, com 32 milhões de idosos.

Assinalado por possuir uma população jovem, o Brasil (Debert. 1999, p. 15), apresentou, até 1970, uma estrutura constante de jovens menores de quinze anos, de adultos de 15 a 64 anos e de idosos de 65 anos ou mais. A queda da fecundidade apresentada a partir de 1980 desemboca em um aumento do peso relativo do segundo e terceiro grupos.

Para Kalache apud Araujo (2000, p.04), em 1940 o Brasil tinha 4\% da sua população de idosos. Estima-se que no ano de 2020 passará a ter 14,7\%, ou seja, em 80 anos a população idosa triplicará. O Brasil terá, então, o equivalente ao número de idosos na França em 1995. Entretanto, no caso da França, foram necessários cento e vinte anos para que esse aumento acontecesse.

Em 1991, no Brasil, de acordo com o IBGE ${ }^{13}$, os indivíduos com 60 anos ou mais somavam 10.722.705. A maior concentração de idosos está localizada na região Sudeste com 10\% de sua população total, na região Sul 09\%, no Nordeste 09\%, no CentroOeste $07 \%$ e ficando com a menor concentração a região Norte com 06\%.

Através de dados do IBGE colhidos na referência acima, verifica-se que a população atual do Brasil, segundo os grupos de idades, é constituída por um número maior de idosos-jovens (60 a 64 anos). As disparidades das expectativas de vida entre os sexos, no Brasil, revelam que, em 1991, as mulheres correspondiam a 54\% da população de idosos; em 2000 passaram para 55,1\%, ou seja, para cada 100 mulheres idosas havia 81,6 homens idosos. As mulheres vivem, em média, oito anos a mais que os homens.

\footnotetext{
${ }^{13}$ Home Page do IBGE, http://www.ibge.gov.br/ibgeteen/datas/idoso/ perfil_idosos.html, acesso em: 04 set. 2003
} 
Ainda de acordo com os dados do IBGE, o Censo 2000, concluiu que 62,4\% dos idosos brasileiros são responsáveis por seus domicílios: um aumento de 60,4\% em relação a 1991. Cabe ressaltar que do conjunto de domicílios brasileiros (44.795.101) 8.964.850 têm idosos como responsáveis, representando $20 \%$ do contingente total. Observa-se, também, que a média de idade do idoso responsável, em 2000, está em torno de 69,4 anos (70,2 anos quando o responsável é do sexo feminino e 68,9 para o idoso responsável do sexo masculino).

Grande parte dos idosos responsáveis pelos domicílios brasileiros 64,7\%, moram com ou sem cônjuge, mas com filhos e/ou outros parentes na mesma casa. A forma de organização familiar mais comum é sem o cônjuge.

Além disso, verifica-se que $80 \%$ da renda do idoso é formada pelos rendimentos de pensão e aposentadoria. O rendimento da população idosa brasileira, de 1991 a 2000, cresceu 63\% e passou de $\mathrm{R} \$ 403,00$ para $\mathrm{R} \$ 657,00$, sendo que na divisão por gênero, os homens possuem uma renda maior do que as mulheres: R\$ 752,00 contra R\$ 500,00 .

Os últimos censos têm demonstrado que a receita média do idoso é menor do que a da população de dez anos ou mais de idade. Todavia, no período analisado acima, seu crescimento atingiu $63 \%$ contra $42 \%$ da população de dez anos ou mais.

Através da Tabela 02, observa-se que, entre as Unidades da Federação - UF, existe uma grande diversidade socioeconômica. Esta afirmação evidencia-se ao analisar a diferença no crescimento dos rendimentos entre as áreas urbanas e rurais. Essa tabela mostra o rendimento médio mensal das pessoas com 60 anos ou mais de idade responsáveis pelo domicílio, no Brasil. 
Tabela 02: Rendimento médio mensal das pessoas com 60 anos ou mais de idade responsáveis pelo domicílio, com rendimento e respectivo crescimento relativo, segundo as Grandes Regiões - 1991 - 2000.

\begin{tabular}{|c|c|c|c|c|c|c|c|c|c|}
\hline \multirow{3}{*}{$\begin{array}{l}\text { Brasil e } \\
\text { Grandes } \\
\text { Regiões }\end{array}$} & \multicolumn{6}{|c|}{$\begin{array}{l}\text { Rendimento médio mensal das pessoas com } 60 \text { anos } \\
\text { ou mais de idade responsáveis pelo Domicílio, com } \\
\text { rendimento (em Reais) }\end{array}$} & \multirow{2}{*}{\multicolumn{3}{|c|}{ Crescimento relativo }} \\
\hline & \multicolumn{3}{|c|}{1991} & \multicolumn{3}{|c|}{2000} & & & \\
\hline & Total & Urbana & Rural & Total & Urbana & Rural & Total & Urbana & Rural \\
\hline Total & 403,00 & 477,00 & 168,00 & 657,00 & 739,00 & 297,00 & 63,00 & 54,00 & 76,00 \\
\hline Norte & 300,00 & 364,00 & 197,00 & 438,00 & 502,00 & 280,00 & 46,00 & 37,9 & 42,1 \\
\hline Nordeste & 224,00 & 298,00 & 115,00 & 386,00 & 474,00 & 198,00 & 72,3 & 59,1 & 72,2 \\
\hline Sudeste & 536,00 & 576,00 & 224,00 & 835,00 & 879,00 & 398,00 & 55,8 & 52,6 & 77,7 \\
\hline Sul & 382,00 & 438,00 & 221,0 & 661,00 & 730,00 & 399,00 & 73,00 & 66,7 & 80,5 \\
\hline Centro-Oeste & 440,00 & 477,00 & 279,00 & 754,00 & 789,00 & 546,00 & 71,4 & 65,4 & 95,7 \\
\hline
\end{tabular}

Fonte: IBGE, Censo Demográfico 1991 e 2000

Nota: Domicílio particulares permanentes

(1) Valores deflacionados pelo INPC com base em julho de 2000

Essa diferença acontece porque nas localidades onde as áreas rurais são mais exploradas economicamente o rendimento médio urbano e rural para os idosos são bastante próximos. Já nas áreas rurais pouco exploradas (regiões Norte e Nordeste), o rendimento médio para os idosos é a metade do urbano.

No ano 2000, a receita dos idosos da área rural representava 40\% da receita dos idosos da área urbana, numa proporção similar à encontrada em 1991, ou seja, os dados apresentados acima, revelam que não houve uma melhora significativa na última década.

O IBGE ${ }^{14}$ declara que após o Censo 2000, o Distrito Federal e o Rio de Janeiro, entre as Unidades da Federação, são as que possuem os maiores rendimentos médios para os idosos (R\$ 1.796,00 e R\$1.018,00, respectivamente), seguidos pelos demais estados da região Sudeste e Sul. Os estados do Nordeste têm os menores rendimentos, com destaque

\footnotetext{
${ }^{14}$ Home Page do IBGE, www.http://www.ibge.gov.br/ibgeteen/datas/i doso/perfil_idosos.html, acesso em: 04 set. 2003
} 
para o Maranhão, onde os idosos recebem, em média, R\$ 287,00. No Rio de Janeiro,

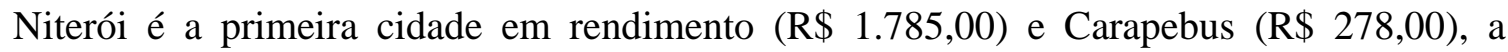
última.

O menor rendimento médio dos idosos (R \$ 572,00) entre as capitais é em Rio Branco, que corresponde a, aproximadamente, um terço dos rendimentos médios de Brasília (R\$ 1.796,00) e de Florianópolis (R\$ 1.790,00).

A renda proveniente do trabalho, com relação aos idosos, não é a responsável pela maior parte da receita familiar. Os resultados da Pesquisa Nacional por Amostra de Domicílios - PNAD, demonstram que, em 1999, os rendimentos originados da aposentadoria representavam 54,1\%, sendo considerados, como principal componente da renda dos idosos, enquanto o rendimento do trabalho correspondia a apenas $36 \%$.

Diante desse evidente aumento da população idosa e de sua participação efetiva na economia brasileira, cabe o questionamento sobre como os movimentos em prol da terceira idade estão acontecendo. 


\section{Lazer e Turismo na Terceira Idade}

Na era moderna, o lazer (Dumazedier, 1979, p. 25) "firmou-se não somente como uma possibilidade atraente, mas também, como um valor.”. Valor, pelo fato de que o lazer não é a negação do trabalho, mas sim, a fuga visando à restauração e à renovação das energias necessárias à qualificação da vida humana e à busca do prazer e do divertimento, satisfazendo assim, suas necessidades. Assim, ao falar de lazer, o autor refere-se às atividades que acontecem no período de tempo livre, depois de atendidas as necessidades da vida e as obrigações do trabalho.

Tempo livre para Andrade (2001, p. 47) nada mais é do que “a pausa na preocupação ou na dedicação produtiva de tarefas sistemáticas que dizem respeito aos diversos atos ou procedimentos relativos ao conjunto de cargos, funções e atividades, lucrativas ou não, em termos de bens diversos, sejam estes materiais ou não.”.

Então, o lazer, de acordo com Dumazedier (1973, p. 34), é “o conjunto de atividades desenvolvidas pelos indivíduos seja para descanso, seja para o divertimento, seja para o seu desenvolvimento pessoal e social, depois de cumpridas suas obrigações profissionais, familiares e sociais.”. Esse conceito resulta nos três “Ds” de Dumazedier, que juntos compõem as três principais funções do lazer (descanso, divertimento e desenvolvimento) sendo solidárias e podendo assim, manifestarem-se simultaneamente em uma mesma situação.

- Função de descanso: o lazer é um reparador dos desgastes físicos e mentais provocados pelas tensões do cotidiano;

- Função do divertimento, recreação e entretenimento: tem um caráter reparador do tédio;

- Função de desenvolvimento: permite uma participação social maior e mais livre, a prática de uma cultura desinteressada do corpo, da sensibilidade e da razão, além da formação prática e tecnológica; oferece novas possibilidades de integração voluntária à 
vida de agrupamentos recreativos, culturais e sociais; cria novas formas de aprendizagem voluntária a serem praticadas, contribuindo para o surgimento de condutas inovadoras e criadoras.

De acordo com Paiva (2000, p. 36), o turismo é visto como uma das representações do lazer. A relação entre lazer e turismo inserida no tempo de cada pessoa é tratada como elemento dinâmico de desenvolvimento cultural. É uma forma de desempenhar as funções essenciais nas estruturas físicas e psíquicas dos indivíduos, caracterizada como uma atividade de liberdade e criatividade e, em nível coletivo, como fator de integração social.

As inúmeras atividades que são desempenhadas na área do turismo não podem ser consideradas de uma forma simplista, pois além de incorporarem características dos serviços em geral e dos produtos turísticos em especial, a avaliação por parte do turista e a satisfação do mesmo é altamente subjetiva, não apenas baseada em fatos reais, mas fortemente afetada por aspectos subjetivos, como suas expectativas e percepções.

(Araujo, 2001, p. 17)

Conforme Hanzin (2000, p. 14) as mudanças no comportamento das pessoas têm influência direta nas novas formas de desenvolver (planejá-lo) e de fazer o turismo. A diminuição do tamanho médio das famílias, o envelhecimento demográfico, a consciência da importância de preservar o meio ambiente e a entrada de jovens no mercado de trabalho caracterizam tendências que se afirmam neste final de século.

Sendo o ser humano a figura central do turismo, todos os esforços devem ser realizados no sentido de que o turista se sinta recompensado pelo investimento que fez ao se deslocar para determinada região ou país. Daí, a importância de se planejar bem o turismo e de se realizarem investimentos, tanto na área de infra-estrutura quanto na qualificação da mão-de-obra e aperfeiçoamento de pessoal. Esses elementos são de 
fundamental importância no mundo competitivo em que vivemos. Nele, a competência é a chave do sucesso.

(ibidem, p. 15)

Na oferta do produto turístico para o segmento da terceira idade, diversos cuidados e aspectos devem ser observados. Para Moletta (2000, p. 09), o público da terceira idade busca no turismo o contato com novas pessoas, benefícios para a saúde, novas culturas, eventos para a confraternização e a vivência de experiências diferenciadas, aliadas ao o meio ambiente ou ligadas à religiosidade.

Ainda conforme o autor acima citado esse público-alvo pode ser subdividido em categorias com diferentes objetivos e formas de agir. Utiliza a seguinte classificação (ibidem, p. 14):

- Grupos de centro de convivência: pessoas que viajam pelo simples prazer de trocar experiências. Saem em excursões programadas pelo setor social do clube em que estão associadas. Este grupo leva em conta o fator econômico do destino escolhido, ou seja, os custos e gastos que envolvem a viagem.

- Grupos de idosos ligados a centros religiosos: formados normalmente por senhoras que realizam trabalhos assistenciais junto a comunidades carentes. Realizam excursões para lugares de interesse religioso e também para o descanso e lazer do grupo ou para confraternizar ao final de um ano de atividades.

- Pequenos grupos independentes: o turista da terceira idade dificilmente viaja sozinho. São freqüentes os casais ou pequenos grupos (no máximo cinco pessoas) que procuram uma agência de viagens e escolhem o destino que será o mais conveniente para o parceiro ou restante do grupo. Eles levam em conta aspectos como distância, meio de transporte, condições de acesso, qualidade e programação do local a ser visitado. Para esse público o fator econômico não tem tanta importância. Buscam excelente qualidade nos serviços e acomodações. Não se importam de retornar várias vezes ao mesmo lugar. 
- Casuais: pessoas que procuram lugares para descansar, são turistas transitórios, em busca de novidades ou simplesmente curiosidade sobre o destino que ouviram falar, que foi indicado por alguém, ou até mesmo descoberto durante a leitura de jornais e revistas. Esse público vai a termas ou spas para conhecer ou experimentar os tratamentos disponíveis. Apreciam as aplicações terapêuticas, mas os efeitos são basicamente psicológicos.

- Pacientes em potencial: pessoas que buscam locais especiais que possuam tratamento medicinal, seja pela água, clima ou outro fator. Eles utilizam a estrutura do local visitado para se tratar, geralmente, essas pessoas estão em pleno tratamento médico e a visita a esses locais tornam-se um complemento recomendado pelo profissional da saúde.

De acordo com Mazo (2001, p. 224), “nos últimos anos é notável a presença de idosos em ambientes hoteleiros e turísticos”. Nota-se, a partir desta afirmação, uma preocupação dos empresários da área em relação ao atendimento desta demanda. Uma demanda que, no futuro, se bem planejada, suprirá totalmente a ausência de turistas na baixa temporada, visto que, por já terem cessado suas obrigações sociais, dispõem de mais tempo livre para gastar em atividades prazerosas como o turismo e o lazer.

Entretanto, conforme Silva (2002, p. 10), o que se percebe por parte dos empresários que estão trabalhando com o turismo da terceira idade são: “...adaptações de programação destinada ao público em geral, que é aceita como única forma de viajar pelo turista com idade acima de 60 anos.”. Eles caracterizam o segmento como uma opção lucrativa na baixa temporada, deixando de lado suas necessidades.

Ao unir o turismo e o idoso é necessário que se leve em conta uma questão: a fragilidade que cerca esse público a ser explorado. Segundo São Paulo (2002, p. 48):

É preciso ter em mente que o idoso pode ser frágil, mas em tese não é tolo. Ele, melhor do que ninguém, conhece suas limitações físicas, principalmente. É óbvio que ele procurará não ir além de suas 
possibilidades, suas forças, ou em outras palavras, não dará o passo maior que as pernas: o idoso irá em busca de algo que lhe possa proporcionar prazer. Não fará um turismo de aventura, por exemplo, talvez nem mesmo um turismo ecológico. Entretanto, um turismo cultural, um turismo religioso, um turismo cívico, podem estar, perfeitamente, dentro de suas pretensões.

Moletta (2000, p.57) afirma ser necessário também a orientação adequada para os profissionais que desejam trabalhar com esse nicho de mercado para o planejamento apropriado do turismo da terceira idade a fim de oferecer melhores condições para o desfrute tanto pelos turistas quanto pela comunidade receptora.

De acordo com o mesmo autor acima citado (ibidem, p. 38) um bom profissional do turismo para a terceira idade tem que apresentar algumas características, como:

- ser extremamente cordial e educado, com muita paciência para ouvir reclamações e sugestões;

- possuir conhecimento geral sobre diversos assuntos, com o propósito de manter um diálogo agradável com os turistas;

- possuir conhecimentos de primeiros socorros, principalmente em casos de emergência (infartos, curativos, medicação para hipertensos e outros);

- ser dinâmico para poder decidir nas horas de emergência ou em situações difíceis.

É importante ressaltar que tais características devem estar presentes em todos os envolvidos com o empreendimento turístico, desde a direção até o porteiro e a telefonista, pois todos entrarão em contato com o cliente. “...o conjunto desses contatos é que contribuirá para a imagem positiva do empreendimento.”.

Para Handszuh apud Araujo (2000, p. 22), o setor turístico deve sempre estar em busca da qualidade em seus serviços e produtos no atendimento ao segmento da terceira 
idade para o melhor atendimento das necessidades desse público. Os fatores básicos da qualidade são:

- segurança: a redução de exposição ao risco propicia ao turista de terceira idade um bem estar psicológico, tranqüilizando-o para melhor aproveitar a viagem;

- limpeza e salubridade: além de ser um fator imprescindível à preservação da saúde do idoso, locais e alimentação em mau estado de limpeza e conservação são interpretados como falta de respeito com os mesmos;

- ambiente: como a apreciação da natureza e da cultura são aspectos de grande importância para as pessoas de mais idade, a promoção de atividades ao ar livre, desde de que devidamente consideradas suas limitações, e de atividades que possibilitem seu envolvimento com a comunidade visitada elevam a qualidade das viagens realizadas;

- acessibilidade: remoção de barreiras arquitetônicas, móveis ergonômicos, suficiente iluminação nos hotéis e nas áreas de acesso, textos (folders, guias, menus), sinais e símbolos fáceis de ler e entender, comunicação oral igualmente compreensível, são algumas facilidades ao turista da terceira idade;

- proteção ao consumidor: as informações prestadas devem ser reais e completas, não criando falsas ilusões e desconhecimento de fatos relevantes, o que, necessariamente, no mínimo, trará frustração e comprometerá o aproveitamento da viagem;

- educação e treinamento: são imprescindíveis algumas atitudes das pessoas que prestam qualquer tipo de atendimento ao turista de terceira idade, dentre as quais cabe ressaltar a hospitalidade (demonstrar aos turistas que são de fato bem aceitos e não apenas em razão de estarem pagando); a cortesia (tratá-los com civilidade e respeito); intelectualidade (entender as necessidades e expectativas dos turistas); a paciência (ouvir e entender seus problemas, bem como aceitar suas limitações); a comunicação eficiente (não usar linguagem profissional e técnica, utilizar uma linguagem normal). 
Voltando a Moletta (2000, p. 38), quando o turismo para a terceira idade é devidamente planejado e orientado, ele resulta em diversos benefícios como: ocupação dos equipamentos turísticos na baixa temporada, incentivo à diminuição dos preços junto às empresas turísticas, expansão e melhoria da rede hoteleira, qualificação da mão de obra, valorização do patrimônio cultural, aumento do intercâmbio entre turistas e a comunidade e melhoria da infra-estrutura da cidade receptora.

O turismo e o lazer para os idosos é um meio de oferecer a este grupo populacional novas perspectivas de vida devido aos conhecimentos que proporciona, ampliando a visão que o ancião tem do mundo em que vive.

Lorda e Sanchez (1998, p. 23) embasam a afirmação acima quando tratam que o lazer deve ser conduzido, como uma possibilidade de

Dar um sentido, uma qualidade a esta terceira etapa da existência, revalorizar as pessoas da Terceira Idade ante seus próprios olhos e os da comunidade, reintegrá-las ao jogo das relações sociais...

Os principais benefícios do desenvolvimento do turismo para o público da terceira idade segundo Mazo (2001, p. 224) são: a manutenção da saúde física e mental, o despertar da alegria e do prazer, o favorecimento para novas descobertas e aprendizagens, a criação de novas amizades, a oportunidade de conhecer outros lugares, a oportunidade de viver novas experiências de vida e de reviver momentos passados em outras épocas, o desejo de desfrutar a vida e o acesso a novas culturas.

O lazer na terceira idade adquire o caráter de suporte social no processo de desenvolvimento contínuo da pessoa ao longo de sua vida. As atividades de lazer para Cavallari e Zacharias, Palma, Marcelino, Bruhns apud Mazo (2001, p.206) auxiliam a:

- Atingir bons níveis de saúde mental e física;

- Desenvolver uma maior integração e participação; 
- Despertar alegria, satisfação e aumentar o desejo de viver;

- Desfrutar a vida, incorporar novas atitudes e valores de convivência;

- Aprender novas linguagens expressivas;

- Desenvolver a capacidade de adaptação e ação a novas respostas motrizes;

- Contribuir para uma melhoria do desempenho cognitivo e global;

- Desenvolver a capacidade criativa e adquirir novas informações;

- Melhorar as tensões emocionais proporcionando autocontrole e confiança;

- Estimular o contato com a natureza.

Entretanto, para que sejam atingidas essas expectativas é necessário que o idoso seja acompanhado por profissionais com capacitação adequada para o desenvolvimento do lazer e do turismo. O turismo não pode ser desenvolvido, nesse segmento, sem estar adequado às suas necessidades.

Pesquisa realizada pela autora deste projeto em seu Trabalho de Conclusão de Curso, apresentado ao Curso de Turismo da Universidade do Sul de Santa Catarina UNISUL, (Galvão, 2002, p. 80) teve como objetivo verificar se o idoso tem consciência da importância do acompanhamento de um profissional capacitado para a realização das atividade de lazer e turismo. Do total da amostra pesquisada (50 entrevistados), 90\% acham importante o acompanhamento de um profissional capacitado para a realização das atividades de lazer e turismo. 


\section{1. Leis e Políticas que Favorecem a Realização do Lazer e do Turismo aos Idosos}

Em 04 de janeiro de 1994 foi sancionada a Lei n. ${ }^{\circ}$ 8.842, (Brasil, 1999, p. 69), que trata da Política Nacional do Idoso, da criação do Conselho Nacional do Idoso e da regulamentação de outras providências.

A Política Nacional do Idoso Capítulo I, Artigos $1^{\circ}$ e $2^{\circ}$, Da Finalidade, considera o idoso a pessoa maior de sessenta anos de idade e tem por objetivo assegurar os direitos sociais do idoso, desenvolvendo condições para promover sua autonomia, integração e participação efetiva na sociedade. (ibidem)

É regida pelos seguintes princípios ${ }^{15}$ :

I. A família, a sociedade e o Estado têm o dever de assegurar ao idoso todos os direitos de cidadania, garantindo sua participação na comunidade, defendendo sua dignidade, bem-estar e o direito à vida;

II. O processo de envelhecimento diz respeito à sociedade em geral, devendo ser objetivo de conhecimento e informação para todos;

III. O idoso não deve sofrer discriminação de qualquer natureza;

IV. O idoso deve ser o principal agente e o destinatário das transformações a serem efetivadas através desta política;

V. As diferenças econômicas, sociais, regionais e particularmente, as contradições entre o meio rural e urbano do Brasil deverão ser observadas pelos poderes públicos e pela sociedade em geral, na aplicação desta lei.

Ainda de acordo com a Política Nacional do Idoso, Das Ações Governamentais (Brasil, 1999, p. 73), o lazer é tratado juntamente com a cultura e o esporte, no Capítulo IV, do Artigo $10^{\circ}$, Parágrafo VII, onde estão definidas as seguintes competências para os órgãos públicos e entidades:

\footnotetext{
${ }^{15}$ Capítulo II, Artigo 3a , Seção I, Dos Princípios, da Política Nacional do Idoso. (Brasil, 1998, p.11)
} 
a) Garantir ao idoso a participação no processo de produção, reelaboração e fruição dos bens culturais;

b) Propiciar ao idoso o acesso aos locais e eventos culturais, mediante preços reduzidos, em âmbito nacional;

c) Incentivar os movimentos de idosos a desenvolver atividades culturais;

d) Valorizar o registro da memória e a transmissão de informações e habilidades do idoso aos mais jovens, como meio de garantir a continuidade e a identidade cultural;

e) Incentivar e criar programas de lazer, esporte e atividades físicas que proporcionem a melhoria da qualidade de vida do idoso e estimulem sua participação na comunidade.

No dia $1^{\circ}$ de outubro de 2003 foi sancionado o Estatuto do Idoso, destinado a regular os direitos assegurados às pessoas idosas, seus principais pontos são (Gramacho, 2003, p. 05):

1. assegura aos idosos o desconto de pelo menos 50\% nas atividades culturais, de lazer e esportivas;

2. garante gratuidade nos transportes coletivos públicos para pessoas com mais de 65 anos;

3. os processos e procedimentos dos atos e diligências judiciais nos quais pessoas acima de 60 anos figurem como intervenientes ganham prioridade;

4. os idosos passam a ter prioridade também na aquisição de moradia própria nos programas habitacionais, mediante reserva de 3\% das unidades. Está prevista, ainda, a implantação de critérios de financiamento da casa própria compatíveis com os rendimentos da aposentadoria ou pensão;

5. os planos de saúde ficam proibidos de discriminar o idoso com a cobrança de valores diferenciados em razão da idade, determinando ainda ao poder público o fornecimento 
gratuito aos idosos de medicamentos, especialmente os de uso continuado, assim como próteses e outros recursos relativos ao tratamento, habilitação ou reabilitação.

O modelo capitalista vigente, no qual o ser humano é valorizado pela sua capacidade de produzir, desprestigiando o inativo, o aposentado, acarretando a exclusão do idoso do convívio social, das políticas públicas de saúde e ação social leva a refletir qual é a implementação prática dessas políticas na sociedade. Para Lima apud Castro (1998, p. 21), o envelhecimento tem se tornado uma questão de ordem pública, sendo hoje não apenas um problema privado e familiar.

No cumprimento de sua missão e para corporificar as competências que lhe foram atribuídas em lei, a EMBRATUR ${ }^{16}$ coordena o Programa Nacional de Clubes de Melhor Idade, que tem como objetivo geral "melhorar o aproveitamento da oferta de equipamentos e serviços turísticos nas baixas temporadas (março a junho e agosto a dezembro), atuando junto ao público denominado de melhor idade”, procurando propiciar a melhoria da qualidade de vida dos brasileiros com mais de 50 anos de idade pelo lazer e pelo turismo.

Esse programa é considerado, pelos órgãos governamentais do Brasil, como um importante instrumento para o desenvolvimento do turismo no país. A importância desse segmento de mercado é verificada pela sua disponibilidade de tempo livre, ocasionando a realização de viagens. A execução do Programa busca contribuir para:

- Geração e manutenção do emprego, tanto direto como indireto, nos estabelecimentos da cadeia produtiva do turismo, especialmente na baixa estação;

- Desestacionalização do turismo pela plena utilização da infra-estrutura hoteleira e de serviços turísticos;

\footnotetext{
${ }^{16}$ Home Page do Instituto Brasileiro de Turismo - EMBRATUR, http://www.embratur.gov.br/programas/ter ceiraidade.hmt, acesso em: 13 ago. 2002.
} 
- Gerar estratégias positivas que dinamizem o setor, através da cooperação entre o setor privado e autoridades públicas, nos diferentes níveis: federal, estadual e municipal;

Os Clubes da Melhor Idade são sociedades civis, sem fins lucrativos, com personalidade jurídica própria, que funcionam como centros de convivência, onde são programadas atividades artísticas culturais, de lazer e recreação, bem como viagens preparadas por agências credenciadas pela EMBRATUR, a custos reduzidos.

No ano de 2002, o convênio com a Associação Brasileira dos Clubes da Melhor Idade - ABCMI, entidade que executa as ações do Programa Nacional dos Clubes da Melhor Idade, não foi renovado devido à existência de pendências relativas à prestação de contas de convênios anteriores.

Uma das ações de destaque do Programa foi a promoção do intercâmbio transnacional. A ABCMI realiza encontros luso-brasileiros, assim como no âmbito do Mercado Comum do Sul - MERCOSUL (Argentina, Brasil, Paraguai e Uruguai). Esse é um trabalho desenvolvido pela EMBRATUR e pelo Instituto Nacional de Aproveitamento dos Tempos Livres - INATEL (Portugal). Anualmente realizam-se os Encontros Luso Brasileiro de Maior Idade que, em 2002, ocorreu em Fortaleza - CE, Brasil, reunindo mais de 3.500 pessoas.

É a partir dessas iniciativas do setor público para facilitar o lazer e o turismo para os idosos, que fazer turismo e lazer, hoje, começa a ser um objetivo exeqüível desse segmento populacional, fato que, no passado, era privilégio de poucos. Porém poucos são os investimentos na área de capacitação de profissionais para atuarem junto a esse público no setor de lazer e turismo. 


\section{Educação}

Para este estudo, foi dividida a história da educação brasileira em quatro períodos distintos: do descobrimento até 1930, de 1930 a 1964, de 1964 até o início da abertura política e do início da abertura política até os nossos dias.

Os três primeiros períodos, tratados na Enciclopédia Almanaque Abril (1992, p. 137), remontam à história da educação propriamente dita. O quarto período trata do período contemporâneo.

Na primeira fase, predominaram o ensino privado e a educação tradicional centrada no adulto, na autoridade do educador e de orientação marcadamente religiosa. Em 1549, os jesuítas da Companhia de Jesus ${ }^{17}$ se instalaram no Brasil passando a dirigir o setor educacional, seguindo os métodos e conteúdos da Ratio Studiorum, que se inspirava nos valores medievais da escolástica. Acusados de conservadorismo cultural pelo governo português, os jesuítas foram expulsos em 1759 do Brasil e de Portugal, nesta época mantinham trinta e seis missões, vinte e cinco residências e dezoito escolas secundárias nos pontos mais importantes do Brasil.

Em 1808, a família real portuguesa traslada-se para o Brasil, fugindo da invasão napoleônica $^{18}$. A preocupação educacional da monarquia limitou-se à formação das elites governantes e dos quadros militares. O príncipe d. João - mais tarde d. João VI - criou o curso de Cirurgia e Anatomia, a Academia Real da Marinha (1808), a Biblioteca Pública (1810), e cursos técnicos e de ensino de artes, com a contratação de artistas franceses.

\footnotetext{
${ }^{17}$ Ordem missionária fundada por Santo Inácio de Loyola em 1534, tendo por objetivo a disseminação da fé para as novas terras de além-mar. O catolicismo, nesse período, sofria oposições de novas doutrinas cristãs “desviantes”. Portanto, a Companhia de Jesus, sob os desígnios da Contra Reforma, deu combate à expansão de doutrinas antagônicas ao catolicismo e ao próprio poder de Igreja. ( Biografias - Enciclopédia Digital, Disco 1, 1996, CD - ROM)

${ }^{18}$ A invasão é conseqüência da aliança de Portugal com a Inglaterra e da rejeição portuguesa ao bloqueio continental decretado pelo imperador francês Napoleão Bonaparte contra o comércio com a Inglaterra. (História do Brasil - Enciclopédia Almanaque Abril, 1998, DC - ROM)
} 
Após a Independência, o país se organizou sob idéias liberais. Essas idéias postulavam que a educação era dever do Estado. Foram criadas, em 1827, as faculdades de Direito de São Paulo e do Recife, onde os representantes das elites eram preparados para ocupar os principais cargos na política, jornalismo, administração pública e advocacia.

O modelo educacional mudou com a Proclamação da República. Em 1890, o governo provisório criou o Ministério da Instrução Pública, Correios e Telégrafos, baseado nas idéias positivistas defendidas por Benjamin Constant ${ }^{19}$. Dois anos depois esse ministério foi extinto. A educação passou, então, para a subordinação ao Ministério da Justiça e Negócios Interiores.

A constituição de 1891 determinou a separação da Igreja do Estado, fazendo com que o ensino das escolas públicas perdesse o seu caráter religioso. Coube aos estados organizar seus sistemas educacionais e à União legislar sobre o ensino superior; ao Congresso atribuiu-se a possibilidade de criação de instituições de ensino superior e médio e a competência de decidir sobre o ensino secundário no Distrito Federal.

Os ventos liberais que passaram a vigorar nas primeiras décadas do século XX culpavam a ignorância do povo por todas as crises do país. Eles influenciaram a política e inspiraram a criação de Escolas Normais (formação de professores de ensino primário) com vistas a erradicar o analfabetismo.

Em 1930, inicia-se o segundo período da história da educação brasileira. Após uma fase de confrontos entre ensinos privado e público, nessa fase o Estado mostra-se permeável a reivindicações populares em razão de compromissos eleitorais do sistema de representação e predominaram idéias liberais, surgindo a "Escola Nova”, centrada na criança e em métodos renovados.

\footnotetext{
${ }^{19}$ Benjamin Constant Botelho de Magalhães. Político e militar. Nasceu em Niterói no Rio de Janeiro, Brasil. Em 1890 é aclamado general-de-brigada, neste mesmo ano passa a chefiar o Ministério da Instrução Pública, Correios e Telegrafos. Defendia a educação como sendo uma prática anuladora das tensões. (Biografias/ Personalidades brasileiras -Enciclopédia Almanaque Abril, 2003, DC - ROM)
} 
Em 1932, o “Manifesto dos Pioneiros da Educação Nova” reivindicava o ensino fundamental público, gratuito, laico e obrigatório. Esse manifesto veio na esteira da recémcriada Associação Brasileira de Educação - ABE. Essas idéias foram o embrião para contemplar a educação com um capítulo na Constituição de 1934, fato inédito na história constitucional brasileira.

O regime implantado após a Revolução de 1930 criou o Ministério da Educação que encarregou-se de todos os planos e projetos ligados ao ensino. O ministro Francisco Campos promoveu uma reforma na qual foi criado o Estatuto das Universidades Brasileiras (1930). Em 1934 foi fundada a Universidade de São Paulo.

Nessa época, percebeu-se a necessidade da elaboração de novas leis e diretrizes para a educação. A Constituição de 1937, promulgada pelo Estado Novo, instituiu o ensino profissionalizante, ou seja, uma educação voltada para o trabalho, para o ensino técnico, considerado como o setor educacional prioritário por se destinar às classes menos favorecidas.

O primeiro projeto de Lei das Diretrizes e Bases da Educação Nacional - LDB, foi encaminhado ao Congresso Nacional pelo ministro Clemente Mariani em 1948. Essa Lei deveria reunir a legislação sobre o assunto em um texto único. O projeto, elaborado por educadores filiados ao movimento da Escola Nova, encontrou oposição das forças tradicionalistas, e só foi promulgado em 1961 através da Lei n. ${ }^{\circ} 4.024$.

Vários movimentos populares surgiram em defesa da educação, no período de redemocratização ${ }^{20}$ política, que vai de 1946 a 1964. Esses movimentos motivaram sucessivas campanhas: de Aperfeiçoamento e Difusão do Ensino Secundário, de Erradicação do Analfabetismo, de Educação de Adultos, de Educação Rural, de Educação

\footnotetext{
${ }^{20}$ Redemocratizar: “Democratizar(-se) novamente.”. (Ferreira, 1994 - 1995, p. 556)

Democratizar: "Levar à democracia; tornar democrático ou democrata. Pôr ao alcance do povo.”.

Democracia: "Governo do povo; soberania popular. Doutrina ou regime político baseado nos princípios da soberania popular e da distribuição eqüitativa do poder, ou seja, regime de governo que se caracteriza, em essência, pela liberdade do ato eleitoral, pela divisão dos poderes e pelo controle da autoridade, isto é, dos poderes de decisão e de execução.”. (Ferreira, 1994 - 1995, p. 200)
} 
do Surdo, de Reabilitação dos Deficientes Visuais, de Merenda Escolar e de Material de Ensino.

O debate educacional intensificou-se no final dos anos 50 e início da década de 60. Em 1963, o sucesso alcançado pela aplicação do método Paulo Freire ${ }^{21}$ despertou a atenção do governo de João Goulart, que tentou expandi-lo para todo o território nacional. Paulo Freire passou a coordenar o Programa Nacional de Alfabetização. Com a Revolução de 1964 esse projeto foi interrompido sendo considerado subversivo e seu autor foi exilado.

A terceira fase caracterizou-se pela educação imposta pelos governos militares. O tecnicismo educacional passou a vigorar e diminuíram os investimentos públicos no setor.

O Regime Militar tornou-se famoso pelas reformas no ensino superior (1968) e no ensino básico (1971), que passou a denominar-se de $1^{\circ}$ e $2^{\circ}$ graus, confirmando a tendência tecnicista e burocrática na educação, principalmente na rede pública. A Educação Moral e Cívica, implantada no Estado Novo, foi reintroduzida como disciplina obrigatória em todos os graus, inclusive na pós-graduação.

Para erradicar o analfabetismo, em 1970 foi instalado o Movimento Brasileiro de Alfabetização - MOBRAL, que tinha como objetivo acabar com o analfabetismo em dez anos, não conseguiu. É importante ressaltar que o método MOBRAL aproveitou em sua didática o método Paulo Freire. A Lei 4.024, Lei de Diretrizes e Bases da Educação Nacional é instituída neste mesmo período, em 1971. A característica marcante desta Lei era tentar dar à formação educacional um cunho profissionalizante, dentro da visão do governo, planejava-se fazer com que a educação contribuísse para o aumento da produção brasileira.

\footnotetext{
${ }^{21}$ Paulo Reglus Neves Freire é internacionalmente conhecido por seu método para alfabetização de adultos, que tem por objetivo, além de ensinar a ler, desenvolver uma visão crítica da sociedade. (Biografias/ Personalidades brasileiras - Enciclopédia Almanaque Abril, 2003, DC - ROM)
} 
Bello $^{22}$ afirma que, com o fim do Regime Militar, pensou-se que se poderiam discutir questões sobre a educação de uma forma democrática e aberta, porém as questões educacionais já haviam perdido o seu sentido pedagógico e assumido um caráter político. Profissionais de outras áreas passaram a falar em educação num sentido mais amplo, assumiram postos na área e concretizaram discursos em nome da educação, já que muitos educadores fora impedidos de atuar em suas funções.

O ministro Paulo Renato de Souza, à frente do Ministério da Educação no Governo do Presidente Fernando Henrique Cardoso (1995-2003), extinguiu o Conselho Federal de Educação e criou o Conselho Nacional de Educação, vinculado ao Ministério da Educação e Cultura. Essa mudança tornou o conselho menos burocrático e mais político.

O Projeto de Lei da nova LDB foi encaminhado à Câmara Federal em 1988 pelo deputado Octávio Elisio. No ano seguinte o deputado Jorge Hage enviou à Câmara um substitutivo ao Projeto e, em 1992, o senador Darcy Ribeiro ${ }^{23}$ apresentou um novo Projeto que foi aprovado em dezembro de 1996. Trata-se da Lei 9.394/96, também denominada de Lei Darcy Ribeiro. Esta Lei veio para atualizar o sistema educacional brasileiro, com 92 artigos.

\section{1. A LDB e a Educação Profissional}

Segundo a Enciclopédia Almanaque Abril (2003, Brasil/Educação, CD ROM), a nova LDB considera que a educação é obrigatória até o ensino fundamental. Prevê a extensão da obrigatoriedade ao ensino médio, neste momento incorporado à educação básica; a aplicação de recursos constitucionais; fixa prazos para repasses dos recursos a estados e municípios; e obriga que esses prestem contas dos gastos. A Lei define claramente as obrigações da União, dos estados e dos municípios.

\footnotetext{
${ }^{22}$ Bello, http://www.pedagogiaemfoco .pro.br/het10. htm, acesso em: 25 nov. 2003

${ }^{23}$ Antropólogo, romancista e político mineiro, é o fundador da Universidade de Brasília. (Biografias/ Personalidades brasileiras - Enciclopédia Almanaque Abril, 2003, DC - ROM)
} 
Cabe à União o dever de formular propostas de organização da educação nacional, avaliar os resultados do desempenho escolar em todos os níveis e reduzir as disparidades regionais, além de manter sua rede de ensino superior.

Aos estados, prioritariamente, cabe organizar e ampliar a escolarização do ensino médio. A LDB transfere aos municípios a responsabilidade pela educação infantil e fundamental.

Ainda de acordo com a Enciclopédia Almanaque Abril (ibidem), entre as virtudes da nova LDB está a inversão da personalidade fortemente normativa e centralizadora que sempre caracterizou o ensino brasileiro, além da flexibilidade e da autonomia como princípios norteadores.

A Lei dispõe, no Capítulo III, Artigo 205, Da Educação, da Cultura e do Desporto (Brasil, 2001, p. 07), que a educação é um direito de todos e dever do Estado e da família e que será promovida e incentivada com a colaboração da sociedade, e visa ao pleno desenvolvimento da pessoa, seu preparo para o exercício da cidadania e sua qualificação para o trabalho.

No Capítulo I, Artigo 21, Das Composições dos Níveis Escolares (ibidem, p. 24), divide a educação escolar em educação básica, formada pela educação infantil; ensino fundamental; ensino médio; e educação superior. Sendo importante ressaltar que a educação profissional é desenvolvida em articulação com o ensino regular e está integrada “às diferentes formas de educação, ao trabalho, à ciência e à tecnologia, conduzindo ao permanente desenvolvimento de aptidões para a vida produtiva.”.

A educação profissional requer, além do domínio operacional de um determinado fazer, a compreensão global do processo produtivo, com a apreensão do saber tecnológico, a valorização da cultura do trabalho e a mobilização dos valores necessários à tomada de decisões.

(Ministério da Educação, 2000 p.103) 
O surgimento da educação profissional no Brasil deu-se como um meio de minimizar o desemprego e dar melhores condições de vida à população menos favorecida. Porém, hoje ela também é vista como uma forma de qualificação e capacitação para o mundo do trabalho. Tendo como objetivos:

I. promover a transição entre a escola e o mundo do trabalho, capacitando jovens e adultos com conhecimentos e habilidades gerais e específicas para o exercício de atividades produtivas;

II. proporcionar a formação de profissionais, aptos a exercerem atividades específicas no trabalho, com escolaridade correspondente aos níveis médio, superior e de pós-graduação;

III. especializar, aperfeiçoar e atualizar o trabalho em seus conhecimentos tecnológicos;

IV. qualificar, reprofissionalizar e atualizar jovens e adultos trabalhadores, com qualquer nível de escolaridade, visando a sua inserção e melhor desempenho no exercício do trabalho.

(Artigo $1^{\text {o }}$, Decreto Federal n. ${ }^{\circ}$ 2.208, De 17 de Abril de 1997, Brasil, 2001, p. 51)

Ainda conforme o Decreto acima citado, a educação profissional dá-se em caráter suplementar à educação básica, ou seja, não substitui a educação básica. Sendo desenvolvida em articulação com o ensino regular ou em modalidades que contemplem estratégias de educação continuada, podendo ser realizadas em escolas de ensino regular, em instituições especializadas ou nos ambientes de trabalho.

Existem três níveis de educação profissional, na legislação em vigor no Brasil, que segundo a Enciclopédia Almanaque Abril (Brasil/ Educação, 2003, DC - ROM) são: básico, técnico e tecnológico.

O nível básico é destinado à qualificação e reprofissionalização de trabalhadores, independentemente de escolaridade prévia. O nível técnico é direcionado a proporcionar habilitação profissional a alunos matriculados ou egressos do ensino médio, devendo ser ministrado na forma estabelecida no Decreto $n .^{\circ}$ 2.208/97. O nível tecnológico 
corresponde a cursos de nível superior na área tecnológica, destinados a egressos do ensino médio e técnico.

A educação profissional de nível técnico, foco deste estudo, é estruturada em áreas profissionais, cada uma com suas respectivas caracterizações, competências profissionais gerais e cargas horárias mínimas de cada habilitação ${ }^{24}$. De acordo com a área, exige-se estágio supervisionado em empresas ou em outras instituições.

O Artigo 5º do Decreto Federal n. ${ }^{\circ}$ 2.208, De 17 de Abril de 1997 (Brasil, 2001, p. 52), estabelece que a educação profissional de nível técnico terá organização curricular própria e independente do ensino médio, podendo ser oferecida de forma simultânea ou seqüencial a este. O Artigo $6^{\circ}$, define que a formulação dos currículos plenos dos cursos do ensino técnico deverão obedecer ao seguinte:

I. O Ministério da Educação e do Desporto, ouvido o Conselho Nacional de Educação, estabelecerá diretrizes curriculares nacionais, constantes de carga horárias mínima do curso, conteúdos mínimos, habilidades e competências básicas, por área profissional.

II. Os órgãos normativos do respectivo sistema de ensino complementarão as diretrizes definidas no âmbito nacional e estabelecerão seus currículos básicos, onde constarão as disciplinas e cargas horárias mínimas obrigatórias, conteúdos básicos, habilidades e competências, por área profissional.

III. O currículo básico, referido no inciso anterior, não poderá ultrapassar setenta por cento da carga horária mínima obrigatória, ficando reservado um percentual mínimo de trinta por cento para que os estabelecimentos de ensino, independente da autorização prévia, elejam disciplinas, conteúdos, habilidades e competências específicas da sua organização curricular.

\footnotetext{
${ }^{24}$ Artigo 5o , da Resolução CNE/CEB n. ${ }^{0}$ 04/99, Brasil, 2001, p. 152
} 
O Artigo $7^{\circ}$ do mesmo Decreto (ibidem, p. 53) trata, ainda, que na elaboração das diretrizes curriculares para o ensino técnico, deverão ser realizados estudos de identificação do perfil de competências necessárias à atividade requerida, ouvidos os setores interessados, inclusive trabalhadores e empregados.

As disciplinas do currículo do ensino técnico, de acordo com o Artigo $9^{\circ}$, serão ministradas por professores, instrutores e monitores selecionados em função de sua experiência profissional e preparados para o magistério, previamente ou em serviço, através de cursos regulares de licenciatura ou de programas especiais de formação pedagógica.

De acordo com o Parecer CNE/CEB n. ${ }^{\circ}$ 16/99 (ibidem, p. 135), a educação de nível técnico abrange, também, cursos ou módulos complementares de especialização, aperfeiçoamento e atualização de pessoal já qualificado ou habilitado nesse nível de educação profissional. Ou seja, são formas de complementação da própria qualificação ou habilitação de nível médio, intimamente vinculadas às exigências e realidades do mercado de trabalho.

A Resolução CNE/CEB n. ${ }^{\circ}$ 04/99 (ibidem, p. 151) instituiu as Diretrizes Curriculares Nacionais para a Educação Profissional de Nível Técnico. Entende-se por diretriz o conjunto articulado de princípios, critérios, definição de competências profissionais gerais do técnico por área profissional e procedimentos a serem observados pelos sistemas de ensino e pelas escolas na organização e no planejamento dos cursos de nível técnico. Os Artigos $5^{\circ}$ e $6^{\circ}$ dessa Resolução definem mais precisamente este parágrafo.

Art. $5^{\circ}$ - A educação profissional de nível técnico será organizada por áreas profissionais, (...), que incluem as respectivas caracterizações, competências profissionais gerais e cargas horárias mínimas de cada habilitação.

Art. $6^{\circ}$ - Entende-se por competência profissional a capacidade de mobilizar, articular e colocar em ação valores, conhecimentos e habilidades necessários para o desempenho eficiente e eficaz de atividades 
requeridas pela natureza do trabalho. Parágrafo único - As competências requeridas pela educação profissional, considerada a natureza do trabalho, são as:

I - competências básicas, constituídas no ensino fundamental e médio;

II - competências profissionais gerais, comuns aos técnicos de cada área;

III - competências profissionais específicas de cada qualificação ou habilitação.

(Quadros Anexos à Resolução CNE/CEB n. 0 04/99, ibidem, p. 157)

Os cursos técnicos na área de hospitalidade e turismo possuem grande potencial de aproveitamento para este estudo, pois ele trata da capacitação de técnicos em turismo para o melhor atendimento da terceira idade. Eles procuram desenvolver competências profissionais para o planejamento, a promoção, a venda, a gestão e a execução do turismo; possuem como finalidade o preparo de pessoas para atuar nesse ramo, com foco principal na prestação de serviços de atendimento ao turista e a operacionalização de equipamentos turísticos e meios de hospedagem e serviços de alimentação; buscam oferecer ao mercado de trabalho uma mão-de-obra qualificada e preparada para as diversas funções da área de turismo e hospitalidade.

Há um grande número de organizações em nível técnico, que oferecem certificação do curso, como por exemplo a Rede Federal (Cefet ${ }^{25}$ e Escolas Agrotécnicas); a Rede Estadual (Instituições Públicas e Privadas sem fins lucrativos) e o Sistema S (Senac ${ }^{26}$, Sebrae $^{27}$ e Senai $^{28}$ ). Essas entidades aprovam os cursos em centros reconhecidos pelo MEC e determinam os papéis de exame que são acessados externamente para estabelecer um certificado dessas organizações. Elas ainda definem a estrutura, a exigência para a entrada e o currículo para as qualificações do curso.

Turismo e Hospitalidade são caracterizados como atividades inter-relacionadas ou não, referentes à oferta de produtos e à prestação de serviços turísticos e de

\footnotetext{
${ }^{25}$ Centros Federais de Educação Tecnológica.

${ }^{26}$ Serviço Nacional de Aprendizagem Comercial.

${ }^{27}$ Serviço Brasileiro de Apoio às Micro e Pequenas Empresas.

${ }^{28}$ Serviço Nacional de Aprendizagem Industrial.
} 
hospitalidade. Os serviços turísticos envolvem o gerenciamento e operação, o guiamento, a promoção do turismo, e a organização e realização de eventos de diferentes tipos e portes. Os serviços de hospitalidade envolvem os serviços de hospedagem e alimentação. Essas atividades são desenvolvidas dentro de um processo que inclui planejamento, a promoção e venda e o gerenciamento da execução.

As competências profissionais gerais do técnico da área são:

- Viabilizar, organizar e conceber produtos e serviços turísticos e de hospitalidade apropriados aos interesses, hábitos, atitudes e expectativas da clientela;

- organizar atividades de lazer, itinerários turísticos, roteiros, eventos, articulando os meios para sua realização com prestadores de serviços e provedores de infra-estrutura e apoio;

- organizar espaços físicos de hospedagem, planejando seus ambientes, uso e articulação funcional e fluxos de trabalho e de pessoas;

- operar a política comercial, realizando prospecção mercadológica, identificação e captação de clientes e adequação dos produtos e serviços;

- operacionalizar a comercialização de serviços turísticos, de hospitalidade e produtos, com direcionamento de ações de venda para o seu público-alvo.;

- avaliar a qualidade dos serviços, produtos e atendimentos realizados;

- executar atividades de gerenciamento econômico, técnico e administrativo dos núcleos de trabalho, articulando os setores internos e coordenando os recursos;

- realizar atividades de gerenciamento pessoal envolvido na oferta dos produtos e na prestação de serviços; 
- executar atividades de gerenciamento dos recursos tecnológicos, supervisionando a utilização de máquinas, equipamentos e meios informatizados;

- realizar a manutenção do empreendimento, dos produtos e dos serviços adequando-os às variações da demanda e

- comunicar-se efetivamente com o cliente, expressando-se em idioma de comum entendimento.

Competências específicas de cada habilitação:

A serem definidas pela escola com o objetivo de complementar o currículo, em função do perfil profissional de conclusão da habilitação.

\section{2. Educação para o Turismo}

O fenômeno determinado pela expansão do turismo tem gerado análises, estudos e pesquisas, tanto no âmbito dos órgão oficias, como no dos setores produtivos e de academias, deixando de ser uma preocupação teórica secundária. De acordo com Moesch (2002, p. 09): o turismo “Converteu-se “em um direito do homem moderno”, segundo Lonati (1986), secretário geral da OMT, passando de um status de objeto percebido a objeto de conhecimento.”.

Para a mesma autora, o turismo é uma combinação de inter-relacionamentos entre produção e serviços. É a integração de uma prática social com base cultural, herança histórica, em meio ambiente diverso, relações sociais de hospitalidade e troca de informações interculturais, resultando na interdisciplinaridade que tem importância fundamental à análise do turismo.

A interdisciplinaridade aponta um método investigativo fecundado sob o ponto de vista epistemológico, desde que superados os nichos 
particularistas existentes nas universidades, nos quais os clássicos campos do saber são criteriosamente delimitados.

(Moesch, 2002, p. 14)

De acordo com Trigo (1998, p. 127), a sociedade brasileira ressente-se da carência de bons profissionais para os diversos trabalhos oferecidos, desde os mais complexos até os mais “simples”.

Segundo o mesmo autor, na verdade, não existem empregos tão "simples" assim; mesmo as atividades mais humildes exigem qualificações consideráveis que uma grande parte da população brasileira não possui. Por exemplo: um caixa de supermercado trabalha com um terminal de computador, uma máquina de leitura ótica de código de barras dos produtos, uma máquina de preencher cheques, uma máquina para cartões de crédito e o controle da esteira do caixa. O mensageiro de um hotel precisa ser bem esperto, pois ele vai orientar o hóspede para seu apartamento, buscar remédios ou artigos de higiene na farmácia, observar quem entra e quem sai do hotel, ser discreto, etc. Portanto, o paradoxo é colocado: há postos de trabalho disponíveis e carência de profissionais capacitados para exercer o trabalho.

Reich (1994, p. 162-165) define os trabalhadores em diversos graus de capacidade intelectual e/ou operacional. São três categorias profissionais:

1. Serviços rotineiros de produção - Possuem semelhança com as tarefas repetitivas do capitalismo taylorista-fordista, como os operários; supervisão simples, como gerentes de baixo e médio nível, supervisores de linha de produção, supervisores administrativos e chefes de seção. Mesmo em setores de alta tecnologia, eles podem ser encontrados, como na montagem de componentes eletrônicos em circuitos impressos ou na codificação de rotina para software e digitadores.

2. Serviços pessoais - Também são tarefas simples e repetitivas, sem grande necessidade de educação escolar aprofundada (no máximo $2^{\circ}$ grau), e, em geral, têm contato direto 
com os clientes. São vendedores de varejo, garçons, empregados de hotéis, zeladores, caixas, atendentes de hospitais e asilos, secretárias, cabeleireiras, motoristas de táxi, corretores de imóveis, comissários de bordo, fisioterapeutas e guardas de segurança.

3. Serviços simbólicos analíticos - São cargos que exigem a capacidade para identificação e solução de problemas e promoção estratégica de vendas. São pesquisadores, engenheiros, executivos de relações públicas, financistas, advogados, promotores de imóveis, consultores em geral, especialistas, headhunters, analistas de sistemas, especialistas em propaganda e marketing, arquitetos, cinegrafistas, editores em geral, escritores, jornalistas, produtores de TV e vídeo, professores universitários.

Atualmente é inconcebível planejar lazer ou turismo sem levar em conta a formação da mão-de-obra especializada que vai trabalhar na área. A partir da afirmativa acima descrita, coloca-se a questão: Como preparar profissionais para o setor de serviços, especialmente para o turismo e lazer? Segundo Trigo (1998, p. 156)

...o tema apontado subdivide-se em uma série de questões subseqüentes e inter-relacionadas que envolvem os paradigmas educacionais para esses novos profissionais, as referências filosóficas que embasam os projetos educacionais e a questão da adequação educacional a mercados cada vez mais dinâmicos e exigentes. Uma reflexão nesse nível mostrou-se assaz multifacetada e capaz de envolver vários campos do conhecimento humano, afinal, o próprio turismo é uma especialidade embasada em várias disciplinas e em outras especialidades.

De acordo com Moesch (2002, p. 133) o turismo, historicamente, é analisado sob as regras da especialização de cada disciplina que o constitui: “a economia, a antropologia, o planejamento, a administração, o marketing , a sociologia, a psicologia, a comunicação...”. Ele carrega a concepção cartesiana de análise; separando o todo, pressupondo um campo de saber, deve explicitar fronteiras cristalinas e um objeto próprio, original. 
Entretanto, a preocupação com a formação profissional em turismo no Brasil e internacionalmente é recente. As diretrizes mais sérias e bem articuladas datam da década de 1990, no Brasil.

Ansarah (2002, p. 73) afirma que os cursos de formação profissional em turismo no Brasil iniciaram-se na década de 1970. Em 1971, é criado o primeiro curso de turismo em nível de graduação, em São Paulo, na Faculdade Anhembi Morumbi e, posteriormente em 1978, os de hospitalidade no Rio Grande do Sul, na Universidade de Caxias do Sul que, inicialmente, os ofereceu em nível tecnológico; mais tarde sediou a Escola Superior de Hotelaria. A evolução dos cursos de turismo no Brasil foi caracterizada por muitas fases. Ansarah as divide em quatro fases. A primeira já está caracterizada acima.

A segunda fase, na década de 1980, é assinalada pela paralisação de cursos em função de problemas econômicos no País, ocasionando o fechamento de vários cursos.

A terceira fase, na década de 1990, foi marcada pela valorização dos cursos no âmbito acadêmico, com o aumento do número de cursos nas áreas de turismo, hotelaria e administração com habilitação em turismo e hotelaria.

A quarta fase, segundo a autora, é a atualidade. Nela está embutida o conceito de "quantidade versus qualidade”, ou seja, “...o aumento quantitativo de propostas diferenciadas de cursos e uma tendência de cursos de turismo com ênfases direcionadas para flexibilização e a regionalização, como recomenda a LDB, 1996.”.

Para Peace apud Trigo (1998, p.160) o turismo, como área de estudo, possui uma exigência válida para ser uma área de conhecimento emergente:

...há cursos formais nas universidades, uma crescente produção em publicações sobre estudos turísticos e um número significativo de redes e organizações de pesquisadores. É preciso, entretanto, devotar ainda bastante atenção para a análise da base do conhecimento em turismo. A caracterização do turismo como uma área de estudo é importante por 
diversas razões e pode ajudar a solucionar algumas questões centrais freqüentemente levantadas por educadores do campo do turismo.

Essas questões referem-se principalmente ao conteúdo programático dos cursos de turismo; à relação entre turismo como área de estudo e outras disciplinas; e ao controle dos programas educacionais em turismo.

É importante ressaltar que, apesar dos grandes avanços conseguidos na área de formação profissional em turismo, seja na docência, seja na pesquisa, ainda existem vários problemas a serem resolvidos.

Os principais problemas que podem comprometer a educação em turismo são apontados por Westlake apud Trigo (2002, p. 165). Ele refere-se à educação nos países desenvolvidos, podendo essa problemática ser adaptada à realidade do ensino brasileiro.

Problemas para o ensino de turismo:

a) O turismo é visto, geralmente, como simples contribuição para enriquecer outras disciplinas como economia ou geografia.

b) A educação em turismo é multidisciplinar e contém elementos atrativos para outras disciplinas como geografia, história e ciência comportamentais (...)

c) Outro problema é que o turismo internacional de massa também é recente (pós-Segunda Guerra Mundial, mais precisamente depois de 1950). Vários fenômenos inéditos (a queda do turismo internacional em 1986 em virtude do acidente em Chernobyl e do terrorismo na Europa Ocidental, por exemplo) não encontram explicações imediatas por causa da inexistência de precedentes. Há também o problema para encontrar dados históricos exatos para validar pesquisas e comparações sobre influências culturais provocadas pelo turismo. É muito mais fácil pesquisar as pessoas em seu "tempo de produção" do que em seu "tempo de ócio ou lazer", por isso a dificuldade em acompanhar sociológica, econômica e culturalmente o fenômeno. 
d) A educação em turismo é também afetada pelo extenso conteúdo da natureza da indústria turística. Ela é fragmentada e atravessa vários setores que envolvem um grande leque de operações. Conseqüentemente, é difícil estudar todos os níveis e as nuanças de um campo razoavelmente indefinido.

e) O setor é dominado por pequenas empresas dirigidas por profissionais empreendedores e auto-suficientes, que não têm treinamento formal em turismo e que, muitas vezes, não reconhecem a necessidade de formação profissional para elevar os padrões da indústria.

Trigo afirma que Westlake (ibidem) pensa que os problemas do turismo associados ao ensino podem ser encarados como uma “crise da meia-idade”. É uma área que ainda não atingiu a maturidade conceitual e metodológica; e não possui a desvantagem do absoluto ineditismo como campo de conhecimento. No Brasil, esse aspecto é bastante evidente, em decorrência do pouco número de bacharéis em turismo com doutorado completo, da escassez da produção de trabalhos acadêmicos nos níveis de mestrado e doutorado e da falta de publicações editoriais.

De acordo com pesquisa realizada por Rejowski apud Moesch (2002, p. 13), em dezessete anos, apenas 55 dissertações e teses foram elaboradas tendo o turismo como objeto.

Conforme Ansarah (2002, p.117) a maioria dos cursos superiores "têm propostas pedagógicas inadequadas” significando que a formação recebida não está de acordo com as necessidades do mercado de trabalho brasileiro.

Para Cooper (2001, p. 493), uma mão-de-obra turística de alta qualidade só poderá ser obtida através de altos padrões de educação e treinamento.

Trigo (1998, p.121) coloca que a educação é um fator diretamente relevante para a atividade do turismo, onde, sobretudo deve-se investir no ensino dos fundamentos de 
leitura, escrita e aritmética; porque, em muitos casos, as escolas não proporcionam educação de qualidade. "Em muitos casos, não estão nem mesmo proporcionando as bases necessárias para trabalhos especializados.”.

A atividade turística pela sua complexidade necessita de mão-de-obra cada vez mais especializada, exigindo dessa não apenas tratar os clientes com cortesia, mas também lidar com roteiros complexos, computadores e aplicações de softwares avançados e clientes cada vez mais exigentes. Trigo (ibidem) trata a educação como fator diretamente relevante para atividade turística.

Os benefícios da educação e do treinamento para o turismo são:

- Garantem que uma alta qualidade de serviço seja prestada ao consumidor.

- Para a atividade como um todo, eles agregam valor, aumentam a qualidade do pessoal e instigam um sentido de profissionalismo e pertinência.

- Auxiliam a definir a atividade e apontam para as semelhanças básicas dos muitos setores (transporte, hospitalidade, atrações, etc).

- As pessoas que trabalham na atividade turística entendem os inter-relacionamentos dos setores e começam a perceber as oportunidades de negócios.

- O treinamento, especificamente, proporciona habilidades e conhecimento prático que estimulam o desempenho e a produtividade do pessoal, e a ligação da educação e do treinamento com o planejamento de mão-de-obra permite um atendimento mais de perto das necessidades do setor por meio da formação das escolas de hotelaria e de turismo.

- Ajudam a manter os funcionários, oferecem um horizonte de carreira e, acima de tudo, proporcionam um sentido mais preciso de recursos humanos na indústria do turismo. 
- Garantem que o produto turístico de uma destinação seja produzido por pessoas locais e não por mão-de-obra vinda de fora.

Ansarah (2002 p.21) afirma que as instituições educacionais têm o dever de direcionar os estudos para a formação de recursos humanos para o mercado de trabalho, estimulando e despertando a preocupação com a pesquisa e a investigação, fornecendo maior embasamento cultural e humanístico, preparando os profissionais para novas tecnologias e novos equipamentos.

\section{3. Levantamento da Oferta de Cursos na Área do Turismo no Brasil}

De acordo com Silva apud Ansarah (2002, p. 16), para que o turismo desenvolva-se a fim de caracterizar uma oferta de qualidade, é fundamental uma formação profissional também de qualidade.

Como o turismo é uma atividade de intensa utilização de capital humano, ainda conforme a mesma autora, só o ensino e a formação da mão-de-obra especializada poderão responder aos desafios que o setor enfrenta, em particular as mudanças tecnológicas que o mundo apresenta e que apontam claramente para as "pluricompetências", que atualmente respondem às exigências competitivas. O sucesso do setor dependerá: da capacidade criativa dos profissionais, da habilidade na introdução de novas tecnologias, do uso de novos processos e formas de organização, da capacitação profissional e da busca constante de produtividade.

Em virtude do tema central deste trabalho, torna-se necessária a apresentação de um levantamento sobre a oferta de cursos na área do turismo no Brasil por parte de instituições de ensino com cursos regulares e livres.

Os dados abaixo apresentados foram coletados através da pesquisa realizada pela Doutora Marília Gomes dos Reis Ansarah em seu livro Formação e Capacitação do Profissional em Turismo e Hotelaria (Ansarah, 2002, p. 81/98). Sua pesquisa consiste no 
levantamento da oferta de cursos em turismo e hotelaria em 2002, realizada com base em fontes secundárias (bibliográficas e documentais), complementada com pesquisa de campo.

Foram pesquisados os cursos existentes de bacharelado em turismo, hotelaria, turismo e hotelaria, gastronomia, lazer/eventos, bacharelado em administração com habilitação em turismo e hotelaria, os tecnológicos e os seqüenciais em turismo e hotelaria, no período compreendido de agosto de 2001 a fevereiro de $2002, \ldots$

Inicialmente foram levantados os cursos de bacharelado especificamente na área de turismo e hotelaria, por estado, como mostra a tabela abaixo.

Conforme a Tabela 03, no Brasil, os cursos de graduação em turismo e hotelaria encontram-se distribuídos em 25 Unidades da Federação, o que é significativo, visto que apenas em duas há falta de cursos de bacharelado especificamente na área de turismo e hotelaria. O levantamento feito pela Doutora Ansarah apresenta um universo de 339 cursos; sendo 293 para turismo, 22 para hotelaria, 19 para turismo e hotelaria, 3 para gastronomia e 2 para lazer/eventos.

Pode-se observar uma maior incidência de oferta de cursos no Estado de São Paulo, com 112 em turismo, 11 em hotelaria, um em turismo e hotelaria e novos cursos de bacharelado, como dois em gastronomia e um em lazer e indústria do entretenimento (este curso foi inserido na categoria do lazer/eventos para efeito de tabulação), os dois últimos oferecidos pela Universidade Anhembi Morumbi, a mesma instituição que iniciou os cursos de turismo no Brasil. (...) vindo em segundo lugar, com uma diferença significativa, o Estado de Minas Gerais (8,8\%), a seguir o Paraná (8,6\%), em quarto lugar o Estado de Santa Catarina (5,9\%) e, a seguir, os Estados da Bahia, com 5,3\% e o de Pernambuco, com 5\%. Os Estados de Rondônia e Tocantins aparecem com uma oferta ainda incipiente, ambos com apenas uma ocorrência, com a preferência pelo curso de turismo. 
Tabela 03: Cursos de bacharelado especificamente na área de turismo e hotelaria no Brasil por Estado - 2002.

\begin{tabular}{|c|c|c|c|c|c|c|}
\hline Estado & Turismo & Hotelaria & $\begin{array}{c}\text { Turismo } \\
\text { e } \\
\text { Hotelaria }\end{array}$ & Gastronomia & Lazer/eventos & Quantidade \\
\hline Amapá & 1 & & & & & 1 \\
\hline Amazonas & 5 & & & & & 5 \\
\hline Pará & 2 & & & & & 2 \\
\hline Rondônia & 1 & & & & & 1 \\
\hline Tocantins & 1 & & & & & 1 \\
\hline Maranhão & 4 & & & & & 4 \\
\hline Ceará & 4 & & & & & 4 \\
\hline $\begin{array}{l}\text { Rio Grande } \\
\text { do Norte }\end{array}$ & 3 & 1 & & & & 4 \\
\hline Pernambuco & 14 & 2 & 1 & & & 17 \\
\hline Paraíba & 4 & & & & & 4 \\
\hline Piauí & 2 & & & & & 2 \\
\hline Alagoas & 2 & & & & & 2 \\
\hline Sergipe & 2 & & & & & 2 \\
\hline Bahia & 14 & 2 & 2 & & & 18 \\
\hline $\begin{array}{l}\text { Distrito } \\
\text { Federal }\end{array}$ & 10 & & & & & 10 \\
\hline Goiás & 6 & & 1 & & & 7 \\
\hline $\begin{array}{l}\text { Mato } \\
\text { Grosso }\end{array}$ & 4 & & & & & 4 \\
\hline $\begin{array}{l}\text { Mato } \\
\text { Grosso do } \\
\text { Sul }\end{array}$ & 10 & & & & & 10 \\
\hline $\begin{array}{l}\text { Minas } \\
\text { Gerais }\end{array}$ & 27 & & 3 & & & 30 \\
\hline $\begin{array}{l}\text { Espírito } \\
\text { Santo }\end{array}$ & 10 & & 1 & & & 11 \\
\hline $\begin{array}{l}\text { Rio de } \\
\text { Janeiro }\end{array}$ & 8 & 1 & & & & 9 \\
\hline São Paulo & 112 & 11 & 1 & 2 & 1 & 127 \\
\hline Paraná & 22 & 1 & 6 & & & 29 \\
\hline $\begin{array}{l}\text { Santa } \\
\text { Catarina }\end{array}$ & 12 & 2 & 4 & 1 & 1 & 20 \\
\hline $\begin{array}{l}\text { Rio Grande } \\
\text { do Sul }\end{array}$ & 13 & 2 & & & & 15 \\
\hline Total & 293 & 22 & 19 & 3 & 2 & 339 \\
\hline
\end{tabular}

Fonte: Ansarah, 2002, p. 83 
A tabela abaixo demonstra a distribuição da oferta de cursos de bacharelado, especificamente em turismo e hotelaria, ao longo de alguns anos, por regiões.

Tabela 04: Distribuição de oferta de cursos de bacharelado especificamente em turismo e hotelaria por região brasileira: 1994, 1996, 2000 e 2002.

\begin{tabular}{|l|c|c|c|c|}
\hline \multirow{2}{*}{ Regiões Brasileiras } & $\mathbf{1 9 9 4}$ & $\mathbf{1 9 9 6}$ & $\mathbf{2 0 0 0}$ & $\mathbf{2 0 0 2}$ \\
\cline { 2 - 5 } & $\mathbf{F}$ & $\mathbf{F}$ & $\mathbf{F}$ & $\mathbf{F}$ \\
\hline Região Sul & 8 & 8 & 47 & 64 \\
\hline Região Suldeste & 21 & 25 & 173 & $177^{29}$ \\
\hline Região Centro-Oeste & 1 & 2 & 30 & 31 \\
\hline Região Nordeste & 9 & 12 & 42 & 57 \\
\hline Região Norte & 2 & 4 & 6 & 10 \\
\hline \multicolumn{1}{|c|}{ Total } & $\mathbf{4 1}$ & $\mathbf{5 1}$ & $\mathbf{2 9 8}$ & $\mathbf{3 3 9}$ \\
\hline
\end{tabular}

Fonte: Ansarah, 2002, p.86

Fazendo uma análise comparativa no que se refere à oferta de cursos, a pesquisa feita por Airey e Johnson, $1998^{30}$ menciona que, de 1991 a 1998, no Reino Unido, os cursos na área aumentaram numa proporção de 350\% em sete anos. No Brasil, de 1994 a 2002 ..., ou seja, em um intervalo de tempo idêntico, o crescimento da área foi de 726,8\%. Fórmula utilizada: $(339: 41-1) \times 100=726,8 \%$

A Tabela 05 apresenta a quantidade de cursos de administração com habilitação em turismo e hotelaria no Brasil por Estado existentes em 2002.

O levantamento feito em 1994 não acusa cursos de bacharelado em administração com habilitação nas áreas de turismo e hotelaria. A primeira ocorrência se dá na pesquisa de 1996. Entretanto, na pesquisa de 2002 surge habilitações com nomes diversos como: administração do turismo, turismo e lazer, turismo e hotelaria, gestão do turismo e hotelaria, gestão do turismo, empreendimentos turísticos, serviços turísticos, gestão de serviços turísticos, turismo, hotelaria, hospitalar e hoteleira, gestão

\footnotetext{
${ }^{29}$ A pesquisa mostra uma pequena diferença na oferta de cursos na região Sudeste (173 em 2000 para 177 em 2002). Na pesquisa de 2002 optou-se por trabalhar somente com cursos em funcionamento.

${ }^{30}$ Airey e Johnson (1998) In: Teixeira, Rivanda Meira, Fletcher, John e Westlake, John. Ensino Superior em
} Turismo do Reino Unido. Turismo em análise. São Paulo: ECA-USP, v. 11 n. 2 nov. 2000, p. 8. 
hoteleira, entre outros. Estas habilitações foram reunidas devido à diversidade de nomes em quatro categorias, a saber: gestão hoteleira, gestão em turismo, gestão em turismo e hotelaria, e gestão em turismo e lazer.

Tabela 05: Cursos de bacharelado em administração com habilitação em turismo e hotelaria no Brasil por Estado - 2002.

\begin{tabular}{|c|c|c|c|c|c|}
\hline Estado & $\begin{array}{c}\text { Gestão } \\
\text { Hoteleira }\end{array}$ & $\begin{array}{c}\text { Gestão em } \\
\text { Turismo }\end{array}$ & $\begin{array}{l}\text { Gestão em } \\
\text { Turismo e } \\
\text { Hotelaria }\end{array}$ & $\begin{array}{c}\text { Gestão em } \\
\text { Turismo e } \\
\text { Lazer }\end{array}$ & Quantidade \\
\hline Ceará & 1 & & & & 1 \\
\hline Piauí & & 1 & & & 1 \\
\hline Pernambuco & 1 & 1 & & & 2 \\
\hline Bahia & 3 & & 1 & & 4 \\
\hline $\begin{array}{l}\text { Distrito } \\
\text { Federal }\end{array}$ & 1 & & & & 1 \\
\hline Goiás & 2 & 1 & 1 & & 4 \\
\hline Minas Gerais & & & 1 & & 1 \\
\hline $\begin{array}{l}\text { Espírito } \\
\text { Santo } \\
\end{array}$ & & 1 & 1 & & 2 \\
\hline São Paulo & 21 & 3 & 1 & 2 & 27 \\
\hline $\begin{array}{l}\text { Santa } \\
\text { Catarina }\end{array}$ & 1 & 1 & 1 & & 3 \\
\hline $\begin{array}{l}\text { Rio Grande } \\
\text { do Sul }\end{array}$ & 1 & 1 & & & 2 \\
\hline Total & 31 & 9 & 6 & 2 & 48 \\
\hline
\end{tabular}

Fonte: Ansarah, 2002, p. 89

Percebe-se que existem 48 cursos de administração com habilitação em turismo e hotelaria em suas quatro categorias e estando sediados em 11 Estados do Brasil - 2002.

Na pesquisa realizada pela Doutora Ansarah o levantamento dos cursos tecnológicos foram feitos separadamente dos cursos de bacharelado em função do crescimento da oferta daqueles, totalizando 20 cursos em todo o Brasil. "Foram consideradas quatro categorias: turismo; hotelaria; turismo e hotelaria; e gastronomia.”. 
Tabela 06: Cursos tecnológicos em turismo e hotelaria no Brasil por Estado - 2002.

\begin{tabular}{|l|c|c|c|c|c|}
\hline \multicolumn{1}{|c|}{ Estado } & Turismo & Hotelaria & $\begin{array}{c}\text { Turismo e } \\
\text { Hotelaria }\end{array}$ & Gastronomia & Quantidade \\
\hline Ceará & 1 & 1 & & & 1 \\
\hline Maranhão & & 1 & & & 1 \\
\hline Bahia & 1 & & & & 1 \\
\hline Goiás & 4 & 6 & 1 & 1 & 12 \\
\hline São Paulo & 1 & & 1 & 2 \\
\hline $\begin{array}{l}\text { Santa } \\
\text { Catarina }\end{array}$ & & 1 & & 1 & 2 \\
\hline $\begin{array}{l}\text { Rio Grande } \\
\text { do Sul }\end{array}$ & $\mathbf{1}$ & $\mathbf{1 0}$ & $\mathbf{1}$ & & $\mathbf{2 0}$ \\
\hline \multicolumn{1}{c}{ Total } & $\mathbf{6}$ & & & & \\
\hline
\end{tabular}

Fonte: Ansarah, 2002, p. 92

Na categoria de turismo, surgem direcionamentos para a gestão turística e tecnologia em turismo. Para hotelaria, surgem tecnologia em hotelaria, em gestão hoteleira, hotelaria e eventos. Em turismo e hotelaria, os direcionamentos são para tecnológo em gestão de serviços de turismo e hotelaria, e, para a categoria de gastronomia, aparecem nomes como tecnologia em gastronomia, tecnológo em alimentos e tecnólogo em viticultura e enologia.

Os cursos seqüenciais apresentam uma grande variedade de ofertas temáticas. Ansarah optou por categorizá-los em turismo, hotelaria, turismo e hotelaria, lazer e entretenimento, geografia do turismo, eventos e gastronomia-alimentos. Os cursos seqüenciais detectados nos levantamento dos dados de 2002 foram:

a) Turismo: agente de turismo, gestão de desenvolvimento do turismo e seqüencial em turismo;

b) Hotelaria: administração financeira e contábil na hotelaria, administração hoteleira, hospedagem, gestão hoteleira e hotelaria;

c) Turismo e Hotelaria: executivo de turismo e hotelaria, e turismo e hotelaria;

d) Lazer e entretenimento;

e) Geografia do turismo;

f) Eventos: organização e gestão de eventos, eventos; 
g) Gastronomia e alimentos: gastronomia e controle de qualidade dos alimentos

Tabela 07: Cursos seqüenciais em turismo e hotelaria no Brasil por Estado - 2002.

\begin{tabular}{|c|c|c|c|c|c|c|c|c|}
\hline Estado & Turismo & Hotelaria & Tur./Hot. & Geo.Tur & Eventos & Lazer/Ent. & $\begin{array}{l}\text { Gast. } \\
\text { Alim }\end{array}$ & Quantidade \\
\hline Pará & 1 & & & & & & & 1 \\
\hline Ceará & 1 & & & & & 1 & & 2 \\
\hline Piauí & & & & 1 & & & & 1 \\
\hline $\begin{array}{l}\text { Rio de } \\
\text { Janeiro }\end{array}$ & & & 2 & & & & & 2 \\
\hline $\begin{array}{l}\text { São } \\
\text { Paulo }\end{array}$ & 1 & 5 & & & 2 & & 2 & 10 \\
\hline $\begin{array}{l}\text { Santa } \\
\text { Catarina }\end{array}$ & & & & & & & 1 & 1 \\
\hline $\begin{array}{l}\text { Rio } \\
\text { Grande } \\
\text { do Sul }\end{array}$ & & & & & & & 1 & 1 \\
\hline Total & 3 & 5 & 2 & 1 & 2 & 1 & 4 & 18 \\
\hline
\end{tabular}

Fonte: Ansarah, 2002, p. 96

O MEC / PROEP /Gerência Técnico-Pedagógica, em setembro de 2002, desenvolveu também uma pesquisa para detectar as escolas financiadas pelo Programa de Expansão da Educação Profissional - PROEP, que oferecem cursos técnicos na área de turismo e hospitalidade. Ela teve como objetivo obter informações da área, para elaboração de um banco de dados para futura ações e pesquisas, que auxiliem o desenvolvimento do projeto pedagógico desses cursos.

Foi verificado que 92 escolas financiadas pelo PROEP têm em seus planos de cursos na área de turismo e hospitalidade. Dessas 92 escolas, nenhuma possui o seu currículo voltado para o turismo da terceira idade. (Anexo A)

A Universidade Católica de Pernambuco, de acordo com Hazin (2000, p. 1356), desenvolveu uma pesquisa para levantar a opinião e a percepção dos empresários da hotelaria da região a respeito da mão-de-obra disponível. A pesquisa foi denominada de “Turismo e mão-de-obra entre o real e o ideal”. Foi concluído que apesar da grande 
quantidade de cursos existentes na área de turismo e hospitalidade, grande parte dos empresários ouvidos consideraram os universitários sem prática, despreparados para enfrentar uma direção/gerência de um estabelecimento hoteleiro, uma vez que a base teórica obtida nos cursos parece não ser suficiente para o desempenho adequado da função. 


\section{Análise e Discussão dos Resultados}

Desde os tempos mais remotos o homem desenvolveu esforços em prol do seu deslocamento. Vários foram os motivos que o levaram a deslocar-se, como a caça, o esporte, a religião, o comércio, a educação etc.

Com o advento das inovações tecnológicas em todos os setores da indústria de serviços, o desenvolvimento da atividade turística tomou um grande impulso, tornando-a acessível a todas as classes sociais.

O turismo, hoje, representa um fenômeno mundial. Gera consumo, origina rendas, cria mercados (nos quais a oferta e a procura encontram-se), resultando num grande e expressivo movimento financeiro, justificando a inclusão da atividade na programação da política econômica de todos os países. É um sistema de serviços que tem como finalidades o planejamento, a promoção e a execução de viagens dos turistas oriundos de suas localidades residenciais.

No Brasil, o setor representou 2,55\% do Produto Interno Bruto - PIB ${ }^{31}$ nacional no ano de 1989, e entre os anos de 1987 a 1995 o PIB turístico passou de R\$ 38,7 bilhões para R \$ 52,7 bilhões, gerando um crescimento de 36\% em menos de dez anos. O turismo tem aumentado o ingresso de divisas no país de maneira considerável. Em 2001, foi de US\$ 4,23 bilhões. Esses dados demonstram o quanto a atividade turística é importante para a melhoria da qualidade de vida da população e da prosperidade da economia brasileira.

Para que o turismo desenvolva-se, entretanto, não basta que o país seja dotado de belezas naturais. É necessário, sobretudo, que haja planejamento e investimento na formação de mão-de-obra especializada para desenvolvimento da atividade.

\footnotetext{
${ }^{31}$ Home Page da EMBRATUR, http://www.embratur.gov.br/0catalogodocumentos/evolucao/Evolucaodoturis monoBrasil19922002.pdf, acesso em: 11 jan. 2004)
} 
A atuação dos profissionais do turismo é decisiva. Eles, além de considerarem os aspectos que devem ser levados em conta, num desenvolvimento harmonioso para a expansão do turismo, estão constantemente atentos para conseguir satisfazer as aspirações de sua clientela.

O ser humano é figura central do turismo, todos os esforços devem ser realizados no sentido de que o turista se sinta recompensado pelo investimento que fez ao se deslocar para determinada região ou país. Daí a importância de se planejar bem o turismo e de se realizarem investimentos, tanto na área de infra-estrutura quanto na qualificação da mão-de-obra e aperfeiçoamento de pessoal.

(Hazin, 2000, p. 15)

Em tempos de globalização, o perfil do consumidor é marcado pela consciência e postura de fazer verem satisfeitas as suas expectativas. A intensidade e a velocidade das mudanças que ocorrem no mercado desafiam as destinações a tomar novos posicionamentos diante da nova realidade, de forma a continuar atendendo às expectativas de suas demandas. A competitividade acirrada, dessa época, contribui para o atendimento das exigências dos consumidores, no que se refere à qualidade do produto/serviço.

A maneira mais adequada para atender melhor o mercado turístico é segmentando-o. A segmentação possibilita o conhecimento dos principais destinos geográficos, tipos de transporte e composição demográfica dos turistas (faixa etária e ciclo de vida; nível econômico ou renda, incluindo a elasticidade-preço da oferta e da demanda; situação social, como escolaridade, ocupação, estado civil e estilo de vida) ${ }^{32}$.

O público analisado nesta pesquisa foi o segmento da terceira idade. As projeções demográficas vêm evidenciando o envelhecimento da população e indicam a necessidade de revisão dos valores e comportamentos ora vigentes.

\footnotetext{
${ }^{32}$ Rodrigues, http://revistaturismo.cidadeinternet.com.br/artigos/artigos.htm, acesso em 15 jan. 2004
} 
Para Becker apud Araújo (2000, p. 12), o aumento da população idosa é fato. Ele aponta que a principal herança do século XX foi o aumento da expectativa de vida, atribuindo esse fato aos avanços no campo da saúde ocorridos a partir de 1900. Ou seja, à medida que as sociedades desenvolvem-se, cresce também a idade de suas populações.

Apesar de muitas pessoas relacionarem essa etapa da vida do ser humano à doença e à morte, o que se percebe, na atualidade, são novos modelos de idosos que estão ditando novas regras e normas que prevalecerão na sociedade. Fazer turismo e lazer começa a ser um objetivo dos idosos, fato que, no passado era privilégio de poucos.

Terceira Idade representa a velhice como uma nova etapa de vida, expressa pela prática de novas atividades sociais e culturais. A representação de estar na terceira idade está vinculada à nova imagem de envelhecimento, onde os indivíduos com idade avançada constroem novos significados, que favorecem a uma participação social, autovalorização, convívio com suas perdas e suas transformações.

(Mazo, 2001, p. 55)

O Censo $2000^{33}$ demonstra que 62,4\% dos idosos brasileiros são responsáveis por seus domicílios, um aumento de 60,4\% em relação a 1991. Diante do evidente aumento da população idosa e de sua participação efetiva na economia brasileira, cabe o questionamento sobre como os movimentos em prol da terceira idade estão surgindo e se realizando.

O governo brasileiro, junto com a Associação Brasileira dos Clubes da Melhor Idade - ABCMI, desenvolveu o Programa Nacional de Clubes de Melhor Idade ${ }^{34}$ que se extinguiu no ano de 2002. Esse programa desenvolveu ações para a melhoria da qualidade de vida dos brasileiros com mais de 60 anos. Entretanto, seu principal objetivo era "melhorar o aproveitamento da oferta de equipamentos e serviços turísticos nas baixas

\footnotetext{
${ }^{33}$ Home Page do IBGE, http://www.ibge.gov.br/ibgeteen/datas/idoso/perfil_idosos.html, acesso em: 04 set. 2003

${ }^{34}$ Home Page da EMBRATUR, http://www.embratur.gov.br/programas/terceiraidade.hmt, acesso em: 13 ago. 2002
} 
temporadas (março a junho e agosto a dezembro), atuando junto ao público denominado de melhor idade”.

A partir dessa afirmação, percebe-se que hoje os esforços para o desenvolvimento do turismo da terceira idade na realidade são (Silva, 2002, p. 10): “...adaptações de programação destinada ao público em geral, que é aceita como única forma de viajar pelo turista com idade acima de 60 anos.”.

De acordo com Mazo (2001, p. 224), “nos últimos anos é notável a presença de idosos em ambientes hoteleiros e turísticos”. O idoso já possui um importante lugar no desenvolvimento da atividade turística no Brasil, visto que, o indivíduo desfruta de mais tempo e recursos financeiros para a retomada de antigos projetos ou para a concepção de novos, já que diminuem as suas obrigações profissionais e a família não requer mais atenção tão significativa. O lazer, nesse momento, é um meio de proporcionar ao ancião a complementação de suas necessidades.

Para os idosos, o desenvolvimento da atividade turística gera alguns benefícios em sua saúde, como a manutenção da saúde física e mental; o despertar da alegria e do prazer; o favorecimento para novas descobertas e aprendizagens; a criação de novas amizades; a oportunidade de conhecer outros lugares, de viver novas experiências de vida e de reviver momentos passados em outras épocas; o desejo de desfrutar a vida; e o acesso a novas culturas. (ibidem)

O crescimento da atividade turística para a terceira idade é fato e traz uma questão que remete à reflexão: é pertinente a capacitação do profissional do turismo para a otimização do atendimento aos idosos?

A capacitação do profissional do turismo para a otimização do atendimento ao idoso é importante em virtude da fragilidade que cerca esse público a ser explorado. Segundo São Paulo (2002, p. 48): 
É preciso ter em mente que o idoso pode ser frágil, mas em tese não é tolo. Ele, melhor do que ninguém, conhece suas limitações físicas, principalmente. É óbvio que ele procurará não ir além de suas possibilidades, suas forças ou, em outras palavras, não dará o passo maior que as pernas: o idoso irá em busca de algo que lhe possa proporcionar prazer. Não fará um turismo de aventura, por exemplo, talvez nem mesmo um turismo ecológico. Entretanto, um turismo cultural, um turismo religioso, um turismo cívico, podem estar, perfeitamente, dentro de suas pretensões.

Para Moletta (2000, p. 09), na oferta do produto turístico para o segmento da terceira idade, diversos cuidados e aspectos devem ser observados, como por exemplo: o público da terceira idade busca no turismo o contato com novas pessoas, benefícios para a saúde, novas culturas, eventos para a confraternização e a vivência de experiências diferenciadas aliadas com o meio ambiente ou ligadas à religiosidade. Essa última afirmação demonstra a inter-relação entre o turismo para a terceira idade e os demais tipos de turismo, ou seja, o de eventos, o cultural, o religioso, o rural etc.

No que se refere a um atendimento de qualidade para esse segmento, Handszuh apud Araujo (2000, p. 22), lista alguns fatores básicos, como: segurança, limpeza e salubridade, ambiente, acessibilidade, proteção ao consumidor, educação e treinamento.

De acordo com Moletta (2000, p. 38), quando o turismo para a terceira idade é devidamente planejado e orientado, ele resulta em diversos benefícios como: a ocupação dos equipamentos turísticos na baixa temporada, o incentivo a diminuição dos preços junto às empresas turísticas, a expansão e melhoria da rede hoteleira, a qualificação da mão de obra, a valorização do patrimônio cultural, o aumento do intercâmbio entre turistas e a comunidade e a melhoria da infra-estrutura da cidade receptora.

Sendo o ser humano a figura central do turismo, todos os esforços devem ser realizados no sentido de que o turista se sinta recompensado pelo investimento que fez ao se deslocar para determinada região ou país. Daí, 
a importância de se planejar bem o turismo e de se realizarem investimentos, tanto na área de infra-estrutura quanto na qualificação da mão-de-obra e aperfeiçoamento de pessoal. Esses elementos são de fundamental importância no mundo competitivo em que vivemos. Nele, a competência é a chave do sucesso.

(Hanzin, 2000 p. 15)

A promoção da capacitação dos profissionais de turismo para a otimização da prestação de serviços ao idoso poderá proporcionar um atendimento de qualidade e estruturado para as necessidades psicossociais desse público.

Além disso, o turismo acaba sendo um instrumento importante para fazer com que as pessoas idosas continuem a ser "interessantes" para o sistema capitalista mesmo depois de encerrada a exploração da força de trabalho, pois, como foi verificado, elas permanecem produtivas para a economia. Os idosos costumam viajar em épocas de baixa temporada, nas quais os movimentos são menores, favorecendo assim, a economia do local; costumam usufruir do lazer e levarem consigo souvenires para toda a família. Esses são alguns exemplos de como os idosos podem contribuir para o sistema capitalista, e, mais importante que isso, o seu tempo livre é um grande atrativo para o sistema, que através do turismo o transforma em lucros.

Para satisfação das expectativas do idoso, em relação à atividade turística, é preciso o planejamento, a fim de oferecer excelentes condições para que ela seja desfrutada. Esse planejamento é composto pela preparação dos atrativos, dos acessos, da infra-estrutura básica, de todo o equipamento turístico, tendo como ponto principal para 0 desenvolvimento dessa atividade junto ao público da terceira idade a capacitação da equipe técnica envolvida, direta e indiretamente.

Pesquisa realizada pela autora deste projeto em seu Trabalho de Conclusão de Curso, apresentado ao Curso de Turismo da Universidade do Sul de Santa Catarina UNISUL, (Galvão, 2002, p. 80) teve como objetivo verificar se o idoso tem consciência da importância do acompanhamento de um profissional capacitado para a realização das 
atividade de lazer e turismo. Do total da amostra pesquisada (50 entrevistados), 90\% acham importante o acompanhamento de um profissional capacitado para a realização das atividades de lazer e turismo.

Percebe-se, dessa maneira, que a capacitação da equipe envolvida direta ou indiretamente com o turismo da terceira idade é o ponto fundamental para o desenvolvimento adequado da atividade, tendo em vista que o idoso é possuidor de um comportamento peculiar. Necessita-se pessoal capacitado para a lida com esse público em todas as áreas de seu interesse, particularmente, quando ele usa o seu tempo para o lazer, especialmente para o turismo.

O nível de exigência e competitividade que marca o meio turístico passa a não se tornar suficiente ao atendimento às expectativas dos consumidores globalizados. Aquele que oferece o produto deve, não apenas satisfazer ao consumidor, mas encantá-lo pela excelência dos serviços.

Os profissionais que trabalham na área precisam estar devidamente capacitados de forma a atender satisfatoriamente aos desejos dos turistas. Daí a importância do componente humano, enquanto elemento estratégico do turismo para a terceira idade. Para tanto, a competência deve-se fazer presente, combinando conhecimentos, habilidades e comportamentos.

A atividade profissional de turismo no Brasil vem crescendo fortemente, envolvendo um número cada vez maior de setores. Com um aumento de 794\% no número de cursos entre 1995 e 2001, o turismo liderou o crescimento percentual da oferta de cursos nesse período, segundo levantamento feito pelo Ministério da Educação. No mesmo período, o número de cursos de administração aumentou $114 \%{ }^{35}$.

Após levantamento realizado no Capítulo 4.3. para a verificação da oferta de cursos na área de turismo no Brasil, percebe-se através da amostra a inexistência de cursos

\footnotetext{
${ }^{35}$ Mendonça et al., http://www.estudosturisticos.com.br/, acesso em: 05 mar. 2004
} 
centralizados no desenvolvimento do turismo para a terceira idade em todos os níveis da educação.

A sociedade brasileira ressente-se da carência de profissionais com capacitação adequada para o desenvolvimento do turismo da terceira idade. Para Cooper (2001, p. 493), uma mão-de-obra turística de alta qualidade só poderá ser obtida através de altos padrões de educação e treinamento. Trigo (1998, p.121) coloca que a educação é um fator diretamente relevante para a atividade do turismo na qual, sobretudo deve-se investir no ensino dos fundamentos de leitura, escrita e aritmética porque, na maioria das vezes, as escolas não proporcionam educação de qualidade. "Em muitos casos, não estão nem mesmo proporcionando as bases necessárias para trabalhos especializados.”.

Ansarah (2002, p.21) afirma que as instituições educacionais têm o dever de direcionar os estudos para a formação de recursos humanos para o mercado de trabalho, estimulando e despertando a preocupação com a pesquisa e a investigação, fornecendo maior embasamento cultural e humanístico, preparando os profissionais para novas tecnologias e novos equipamentos.

Dentro de todos os níveis de educação analisados, a capacitação de técnicos em turismo para o melhor atendimento da terceira idade foi selecionada para ser tema central deste estudo. Esse tipo de educação profissional foi escolhida por apresentar-se como uma forma de oferecer educação especializada (qualificada e preparada) em curto prazo de tempo para o mercado de trabalho. O aumento da demanda do público em questão precisa, o quanto antes, de profissionais gabaritados para o desenvolvimento do turismo junto ao público da terceira idade.

A educação profissional requer, além do domínio operacional de um determinado fazer, a compreensão global do processo produtivo, com a apreensão do saber tecnológico, a valorização da cultura do trabalho e a mobilização dos valores necessários à tomada de decisões.

(Ministério da Educação, 2000 p.103) 
Os cursos técnicos, na área de hospitalidade e turismo, possuem grande potencial de aproveitamento. Eles procuram desenvolver competências profissionais para o planejamento, a promoção, a venda, a gestão e a execução do turismo. Possuem como finalidade o preparo de pessoas para atuar no mercado turístico, tendo como foco principal a prestação de serviços de atendimento ao turista e a operacionalização de equipamentos turísticos e meios de hospedagem e serviços de alimentação.

A importância da educação profissional de nível médio é verificada na citação de Moletta (2000, p. 38), onde a autora elenca os pré-requisitos da equipe envolvida com o turismo da terceira idade, a saber: ser extremamente cordial e educado, possuir conhecimentos gerais sobre temas diversos, possuir conhecimentos de primeiros socorros e ser dinâmico para não perder o controle nas horas de emergência.

O último levantamento do Ministério do Turismo aponta que, em 2001, as atividades relacionadas ao turismo empregavam 1,3 milhão de pessoas. Este é um mercado de trabalho que cresce a cada dia, mas também exige que os profissionais aprimorem sua formação constantemente.

De acordo com pesquisa feita por Flores ${ }^{36}$ junto ao diretor de planejamento da Traveland Viagens e Turismo, o último afirma que

...tem sido muito difícil encontrar bons profissionais e com experiência. Estamos procurando um operador internacional há três meses e não encontramos ninguém que satisfaça os requisitos da vaga (...) Não é a primeira vez que enfrentamos tal dificuldade. Algumas vezes, a fluência do inglês não nos satisfaz, outras vezes os candidatos têm dificuldades na prova de raciocínio quantitativo...

Para o diretor, as empresas são qualificadas de acordo com os serviços prestados, que dependem do desempenho de seus funcionários. “É imprescindível que a

\footnotetext{
${ }^{36}$ Flores, http://www.estudosturisticos.com.br/, acesso em: 05 mar. 2004
} 
formação do profissional leve em consideração a realidade do mercado brasileiro, que está extremamente competitivo", afirma.

O turismo é uma atividade econômica que vive do imaginário, devendo permitir a realização dos sonhos dos turistas. A arte de bem servir e receber torna-se, dessa maneira, uma condição essencial. O atendimento profissional deve ser, então, acrescentado ao espírito hospitaleiro, compondo um capital humano capacitado para atender à demanda.

Talvez a única certeza do turismo seja a de mudanças permanentes. No entanto, a partir do momento em que os esforços sejam direcionados para que seja alcançada uma educação voltada para a cultura de saciar as expectativas dos turistas, investindo na capacitação contínua dos profissionais que atuam na área, o cenário do turismo no Brasil pode ficar menos vulnerável às incertezas.

Dessa forma, o turismo para a terceira idade no Brasil irá deixar de ser desenvolvido de forma amadora e se profissionalizará rumo ao domínio desse segmento de mercado. 


\section{Conclusão}

A diminuição nas taxas de natalidade e as recentes tecnologias na área da saúde estão ensejando o envelhecimento da população brasileira e mundial. Essa informação, acrescida da constatação de que o idoso é, normalmente, uma pessoa com tempo livre e maior disponibilidade de receita para gastar em viagens levou à preocupação de capacitar recursos humanos para a lida com esse público.

Para uma primeira aproximação do tema escolhido foi abordada a história do turismo, as definições e a importância econômica do mesmo como um meio para o entendimento do quanto o turismo, como atividade profissional, vem crescendo no Brasil e envolvendo um número cada vez maior de setores.

O ser humano tem uma vocação para o turismo que remonta os nossos mais antigos ancestrais. Os povos deslocavam-se para satisfazer suas necessidades básicas de encontrar novas fontes de água, coletar frutos ou encontrar caça quando esta escasseava em seu ambiente. Ao longo dos anos muitos foram os motivos que fizeram o homem viajar. Hoje, realizam-se viagens de um lugar ao outro por diversas razões como eventos, religião, saúde, educação, entre outros.

No século XX, o turismo passou a integrar a vida das nações. O aumento das horas livres, com a redução dos custos nos transportes e a aumento da velocidade dos meios de comunicação, tornou os povos mais próximos. Alguns desses fatores contribuíram para que o homem atual tenha acesso a mais informações sobre as atrações turísticas em nível planetário.

O turismo é uma das atividades econômicas que mais geram empregos e divisas, quer em países em desenvolvimento, quer nas nações desenvolvidas. As cifras que o turismo é capaz de movimentar, em todo o mundo, impressionam e atuam como agente motivador das localidades, ocasionando um crescimento, em alguns casos, desenfreado, de equipamentos e serviços que possam ser utilizados pela demanda, cada vez maior. 
O crescimento contínuo da demanda provoca um aumento das cifras movimentadas pela atividade, gerando então um ciclo que se resume no crescimento e investimento no turismo em função exclusiva dos benefícios econômicos trazidos pela atividade. Desta forma, é demonstrada a importância do turismo para a melhoria da qualidade de vida da população e da prosperidade da economia brasileira.

O público estudado nesta pesquisa foi o da terceira idade em virtude do grande aumento estimado dessa população nos próximos vinte anos. Em relação à participação desse segmento na economia brasileira, verifica-se que possui uma participação relevante. Esse segmento caracteriza-se como um mercado bastante promissor para a indústria do turismo por possuir muito tempo livre e um nível econômico relevante. O turismo cumpre sua função básica de transformar o tempo livre em lazer.

Alguns esforços já estão sendo tomados em prol da otimização do tempo livre do idoso. Todavia, a falta de profissionais preparados para análise de perfis de público-alvo leva a que as principais medidas tomadas sejam, principalmente, para ocupar lacunas de sazonalidade, ou seja, tornando disponível ao idoso vagas em baixa temporada, quando os transportes, leitos e atrativos turísticos ficam praticamente ociosos.

Entretanto, para que as necessidades das demandas sejam corretamente satisfeitas, o turismo não pode ser trabalhado apenas como fator de desenvolvimento econômico, mas também como fator de realização de sonhos. O turismo gera dinheiro através do imaginário do público-alvo. Assim sendo, os empresários do setor devem estar atentos às nessecidades do seu cliente. O investimento na mão-de-obra especializada no setor do turismo aparece como a forma mais correta para a qualificação da prestação dos serviços prestados e para o melhor atendimento a esse novo tipo de consumidor.

A falta de cursos para formar profissionais que lidem com um público tão especial, enseja um estudo mais criterioso do que possa ser feito para a criação e/ou adaptação de currículos em nível técnico que atendam a essa demanda. 
O histórico de crescimento dos cursos de turismo, aliado a uma legislação que incentiva a capacitação de cabeças pensantes especializadas e um setor carente de profissionais leva à formatação da idéia de formar mão-de-obra qualificada para desenvolver um trabalho de excelência junto ao público sênior.

Enfim, a investigação da importância de capacitar profissionais do turismo em nível técnico mostrou-se exeqüível e urgente a fim de que não se perca a oportunidade de conquistar definitivamente esse nicho de mercado, colocando o Brasil como referência no turismo da terceira idade. 


\section{Referências Bibliográficas}

ALTA VISTA. Tradutor. Brasília, jan., 2004. Home page Alta Vista, Seção: Ferramentas, Tradutores. Disponível na Internet em: http://babelfish.altavista.com/babelfish/tr, acesso em: 15 jan. 2004.

ANSARAH, M. G. R. e outros. Turismo - Como Aprender, Como Ensinar - Volume Dois. São Paulo: Senac, 2001.

ARAUJO, Cleida Maria Silva. Turismo para terceira idade: refletindo o futuro. Balneário Camboriú/SC, Universidade do Vale do Itajaí - UNIVALI, 2000, 30pág. (Monografia apresentada ao Curso de Pós-Graduação em Turismo: Planejamento, Gestão e Markenting)

BARRETTO, Margarita. Manual de iniciação ao estudo do turismo. Campinas, SP: Papirus, 1995 (Coleção Turismo).

BELLO, José Luiz de Paiva. História da Educação no Brasil. Brasília, fev., 2003. Home Page Pedagogia em Foco. Seção: História. Disponível na Internet em: http://www.peda gogiaemfoco.pro.br/het10. htm, acesso em: 25 nov. 2003

BENTO, Jorge Olímpico. O século do idoso e o papel do desporto. Humanidade, p. 14 23, out. 1999.

BRASIL, Distrito Federal. Secretaria do Governo. Subsecretaria para Assuntos do Idoso. A terceira idade no Distrito Federal. Brasília: Starprint, 1999.

BRASIL, Ministério da Educação. Educação Profissional - Legislação Básica. $5^{\mathrm{a}}$ ed. Brasília: MEC, 2001

BRASIL. Ministério da Educação. Educação Profissional - Referencias Curriculares Nacionais da Educação Profissional. Brasília: MEC, 2000.

BRASIL. Poder Executivo Ministério da Justiça. Política Nacional do Idoso e Programa Nacional de Direitos Humanos. Brasília: Ministério da Justiça, Secretaria Nacional dos Direitos Humanos, 1998. 
CARVALHO, Caio de Luiz. discurso [mai. 2002]. $7^{\mathbf{0}}$ Encontro dos Clubes da Melhor Idade e $6^{\mathbf{0}}$ Encontro Luso-Brasileiro da Melhor Idade. Fortaleza, mai., 2002. Assessoria de Comunicação Social. Disponível na Internet em: www.met.gov.br/notícias, acesso em: 19 set. 2002.

CASTELLI, Geraldo. Turismo: atividade marcante do século XX. $3^{\text {a }}$ ed. rev. e amp. Caxias do Sul: EDUCS, 1996.

CASTELLI, Geraldo. Turismo: atividade marcante. $4^{\text {a }}$ ed. rev. e amp. Caxias do Sul: EDUCS, 2001.

CASTRO, Odair Perugini. Velhice que idade é esta? Porto Alegre: Síntese, 1998.

COOPER, Chris; Fletcher, J.; WANHILL, D.; SHEPHERD, R. Turismo, princípios e práticas. Trad. Roberto Cataldo Costa, 2ªed. Porto Alegre: Bookman, 2001.

COSTA, Elisabeth Maria Sene. Gerontodrama: a velhice em cena. São Paulo: Ágora, 1998.

COSTA, Marco Antonio F. da; COSTA, Maria de Fátima Barrozo da. Metodologia da pesquisa: conceitos e técnicas. Rio de Janeiro: Interciência, 2001.

DEBERT, Guita Grin; NERI, Anita Liberalesso (orgs.). Velhice e sociedade. Campinas, SP: Papirus, 1999. (Coleção Vivaidade)

DUMAZEDIER, J. Lazer e cultura popular. São Paulo: Perspectiva, 1973.

DUMAZEDIER, J. Sociologia empírica do lazer. São Paulo: Perspectiva, 1979.

EMBRATUR. Programas e projetos. Brasília, ago., 2002. Home Page Instituto Brasileiro de Turismo - EMBRATUR. Seção Programas: Terceira Idade. Disponível na Internet em: http://www. embratur.gov.br/programas/terceiraidade.hmt, acesso em: 13 ago. 2002.

EMBRATUR . Coletânea da evolução do turismo no Brasil 1992 - 2002. Brasília, jan., 2004. Home Page do Instituto Brasileiro de Turismo - EMBRATUR. Seção: Profissionais, Dados e Fatos, Estatísticas e Indicadores, Evolução do Turismo no Brasil. http://www. 
embratur.gov.br/0-catalogo-documentos/evolucao/evolucaodoturismonoBrasil19922002.pd f, acesso em: 11 jan. 2004

ENCICLOPÉDIA ALMANAQUE ABRIL 1992. Ano XVIII, São Paulo: Ed. Abril, 1992.

ENCICLOPÉDIA ALMANAQUE ABRIL 1998. São Paulo: Ed. Abril, 1998. DC - ROM

ENCICLOPÉDIA ALMANAQUE ABRIL 2003. São Paulo: Ed. Abril, 2003. CD - ROM

ENCICLOPÉDIA DIGITAL - EM MULTIMÍDIA. Disco 1, Manaus: GLLG Informática, 1996. CD - ROM

FERREIRA, Aurélio B. H. Dicionário Aurélio básico da língua portuguesa. Folha de S. Paulo, Rio de Janeiro: Nova Fronteira, 1994 - 1995.

FERREIRA, Aurélio B. H. Novo Aurélio Século XXI: o dicionário da língua portuguesa. $3^{\text {a }}$ ed. rev. amp. Rio de Janeiro: Nova Fronteira, 1999.

FLORES, Paulo. Faltam Profissionais Especializados no Mercado. Brasília, nov., 2003. Home Page Estudos Turísticos, Seção: Artigos. Disponível na Inetrnet em: http://www.estudosturisticos.com.br/, acesso em: 05 mar. 2004

GAELZER, Lenea. Lazer: benção ou maldição? Porto Alegre, RS. Ed. Sulina, 1979.

GALVÃO, Daniele Linhares. O lazer e o turismo para a terceira idade como alternativa de otimização do tempo livre, na visão dos participantes dos grupos: NETI - Núcleo de Estudos da Terceira Idade e GETI - Grupo de Estudos da Terceira Idade. Florianópolis/SC, Universidade do Sul de Santa Catarina - UNISUL, 2002, 99pág. (Trabalho de Conclusão de Curso apresentado ao Curso de Turismo: Gestão do Turismo)

GRAMACHO, Maiesse. Jornal da comunidade. Brasília, 28 set. 2003, Série Idoso, p. 05.

HAZIN, Ana Lúcia. Turismo e Mão-de-obra: entre o real e o ideal. Recife: Fundaj: Unicap. 2000. 
LICKORISH, Leonard J.; JENKINS, Carson L. Introdução ao turismo. Tradução de Vasconcellos, Fabíola de Cavarlho S. 2ª Tiragem. Rio de Janeiro: Campus, 2000.

LORDA, C. Raúl; SANCHEZ, Carmem Delia Recreação na terceira idade. $2^{\text {a }}$ ed. Rio de Janeiro: Sprint, 1998.

MAZO, Giovana Zarpellon. Atividade fỉsica e o idoso: concepção gerontológica. Porto Alegre: Sulina, 2001.

MENDONÇA, Maria Cristina Angélico de. et al. A indústria do turismo: história, características e tendências. Brasília, jul., 2003. Home Page Estudos Turísticos, Seção: Turismo, História. Disponível na Internet em: http://www.estudosturisticos.com.br/, acesso em: 05 mar. 2004

MINISTÉRIO DA EDUCAÇÃO - SECRETARIA DE EDUCAÇÃO MÉDIA E TECNOLÓGICA. Diretrizes curriculares nacionais para a educação profissional de nível técnico. Brasília: Setembro/2000.

MOESCH, Marutschka Martini. A produção do saber turístico. 2 ed. São Paulo: Contexto, 2002.

MOLETTA, Vania Florentino. Turismo para a terceira idade. $2^{\mathrm{a}}$ ed. Porto Alegre: SEBRAE/RS, 2000. (Série Desenvolvendo o Turismo, 7)

OLIVEIRA, Antonio P. Turismo e desenvolvimento: planejamento e organização. $3^{\mathrm{a}}$ ed. rev. e ampl. São Paulo: Atlas, 2001.

REICH, Roberto B. O trabalho das nações. São Paulo: Educator, 1994.

RODRIGUES, Ricardo. Segmentação do Turismo. Brasília, jan., 2004. Home Page Revista Turismo, Seção Artigos. Disponível na Internet em http://revistaturismo.cidadein ternet.com.br/artigos/artigos.htm, acesso em 15 jan. 2004

RUSCHMANN, Doris. Marketing turístico: um enfoque promocional. $5^{\mathrm{a}}$ ed. Campinas. SP: Papirus, 1990 (Coleção Turismo). 
SANCHOS, Amparo. OMT - Introdução ao turismo. Tradução: Corner, Dolores Martin Rodriguez. São Paulo: Roca, 2001.

SÃO PAULO, Vera de. O idoso e o turismo. Brasília/DF, Universidade de Brasília UNB, Centro de Excelência em Turismo, 2002, 93pág. (Monografia apresentada ao Curso de Pós-Graduação em Gestão e Marketing do Turismo)

SECOND INTERNATIONAL CONFERENCE ON SENIOR TURISM, 12 - 15 SET. 1996, Recife/Olinda, Estado do Pernambuco, Brasil. Proceedings - Selected Materials. Madri, Espanha: World Tourism Organization, 1997. 89 pág.

SILVA, Fatima Sueli de Souza. Turismo e psicologia no envelhecer. São Paulo: Roca, 2002.

SOCIAL, Comunicação. Perfil dos idosos responsáveis pelos domicílios. Brasília, jul., 2002. Home Page do Instituto Brasileiro de Geografia e Estatística - IBGE. Seção População: Indicadores Sociais. Disponível na Internet em: http://www.ibge.gov.br/home/p residencia/noticias/25072002pidoso.shtm, acesso em: 04 nov. 2003.

TRALDI, Maria Cristina; Dias, Reinaldo. Monografia Passo a Passo. $3^{\mathrm{a}}$ ed. Campinas, SP: Alínea, 2001.

TRIGO, Luis Gonzaga Godoi. A Sociedade Pós-Industrial e o Profissional em Turismo. Campinas, SP: Papirus, 1998. (Coleção Turismo) 
ANEXO

Anexo A - Instituições que oferecem cursos na Área de Turismo e Hospitalidade Financiadas pelo MEC/PROEP. 
ESCOLAS PROEP

Cursos Técnicos na Área de Turismo e Hospitalidade

\begin{tabular}{|c|c|c|c|}
\hline $\mathbf{N}^{\mathbf{0}}$ & ESCOLA & SEGMENTO & CURSO \\
\hline 1 & Centro Federal de Educação Tecnológica de São Paulo - UNED/Cubatão & Federal & Turismo \\
\hline 3 & Escola Técnica Federal de Sergipe & Federal & Turismo \\
\hline 5 & Centro Federal de Educação Tecnológica do Maranhão & Federal & Turismo \\
\hline 6 & Escola Agrotécnica Federal de Bambuí & Federal & Turismo e Hospitalidade \\
\hline 7 & Escola Técnica Federal de Mato Grosso & Federal & Hotelaria e Turismo \\
\hline 10 & Escola Técnica Federal de Ouro Preto & Federal & Turismo \\
\hline 11 & Centro Federal de Educação Tecnológica de Alagoas & Federal & $\begin{array}{l}\text { Alimentos, Turismo, Administração de Eventos, Hotelaria e } \\
\text { Animação Turística }\end{array}$ \\
\hline 12 & Escola Técnica da Universidade Federal do Rio Grande do Sul & Federal & Ecoturismo \\
\hline 13 & Centro Federal de Educação Tecnológica da Paraíba & Federal & Turismo \\
\hline 14 & Centro Federal de Educação Tecnológica de Pernambuco & Federal & Turismo \\
\hline 15 & Centro Federal de Educação Tecnológica do Rio Grande do Norte & Federal & Turismo \\
\hline 20 & Escola Agrotécnica Federal de Cáceres - MT & Federal & Ecoturismo \\
\hline 21 & Centro Federal de Educação Tecnológica do Espírito Santo - Sede & Federal & Turismo \\
\hline \multirow[t]{2}{*}{22} & Escola Agrotécnica Federal de Sombrio & Federal & Turismo e Turismo Rural \\
\hline & Centro Federal de Educação Tecnológica de Goiás (Curso Tecnológico) & Federal & Hotelaria e Turismo \\
\hline 23 & Colégio Agrícola Frederico Westphanlen - RS & Federal & Turismo \\
\hline 24 & CEFET - Pará & Federal & Planejamento de eventos \\
\hline 25 & CEFET - Campos - Uned Macaé & Federal & Turismo, Agente de Viagens e Orgnização de Eventos \\
\hline 26 & Escola Técnica Federal de Sergipe & Federal & Serviços Turísticos Hoteleiros \\
\hline 27 & Centro Federal de Educação Tecnológica da Bahia & Federal & $\begin{array}{l}\text { Agenciamento, Eventos, Hospedagem, Produção Cultural e } \\
\text { Guiamento. }\end{array}$ \\
\hline 28 & Centro Federal de Educação Tecnológica de Petrolina & Federal & Turismo \\
\hline 29 & CEFET - CE & Federal & Turismo \\
\hline
\end{tabular}


ESCOLAS PROEP

Cursos Técnicos na Área de Turismo e Hospitalidade

\begin{tabular}{|c|c|c|c|}
\hline 36 & Escola Técnica Estadual "Aristóteles Ferreira" & Estadual & $\begin{array}{l}\text { Hotelaria e Alimentação e Hotelaria e Gestão de Alimentos e } \\
\text { bebidas }\end{array}$ \\
\hline 38 & CEP - São Luis - MA & Estadual & Turismo e Hotelaria \\
\hline 40 & CEP - Catalão - GO & Estadual & Hotelaria e Planejamento Turístico \\
\hline 41 & CEP - Poranguatu - GO & Estadual & Admistração Hoteleira e Planejamento Turístico \\
\hline 42 & CEP - Caiapônia - GO & Estadual & Admistração Hoteleira e Planejamento Turístico \\
\hline 43 & CEP - Salvaterra - PA & Estadual & Administração Hoteleira \\
\hline 46 & Centro Regional de Educação Profissional de Caxambu - MG & Estadual & $\begin{array}{l}\text { Serviços de Hospitalidade, Administração e Meios de } \\
\text { Hospedagem, Agenciamento e Operações Turísticas, Alimentos } \\
\text { e Bebidas, Guia de Excursão Nacional, Excursão Regional e } \\
\text { Organização de Eventos }\end{array}$ \\
\hline 47 & CEP - São João - PB & Estadual & Recreação \\
\hline 48 & Escola do Trabalho e Produção - Tailândia - PA & Estadual & Gerência de Hotelaria \\
\hline 53 & Centro Técnico Estadual Santa Maria - RS & Estadual & em Alimentos \\
\hline 54 & CEP- José de Figueiredo Barreto & Estadual & Turismo e Hospitalidade \\
\hline 55 & CEP de Capão Bonito & Estadual & Turismo \\
\hline 56 & CEP Boa Vista - RR & Estadual & Técnico em Turismo e Hospitalidade \\
\hline 57 & Centro de Educação Profissional da UNICAMP - COTUCA & Estadual & Turismo e Hospedaria \\
\hline 58 & CEP - Sapopemba & Estadual & Turismo e Hospitalidade \\
\hline 59 & Escola Bahiana - BA & Comunitário & Alimentos \\
\hline 60 & Centro de Gastronomia Alimentação e Artes - SC & Comunitário & $\begin{array}{l}\text { Turismo, Admistração da Culinária, Administração de } \\
\text { Restaurantes, Administração de Cozinha Industrial, Artes } \\
\text { Culinárias / Mestre de Cozinha e Artes Culinárias / Mestre } \\
\text { Confeitaria }\end{array}$ \\
\hline 61 & Escola de Turismo e Hotelaria Canto da Ilha - SC & Comunitário & Artes Culinárias/Mestre em Panificação e Turismo \\
\hline 62 & Centro e Educação Tecnológica - Timóteo - MG & Comunitário & Turismo e Lazer \\
\hline
\end{tabular}


ESCOLAS PROEP

Cursos Técnicos na Área de Turismo e Hospitalidade

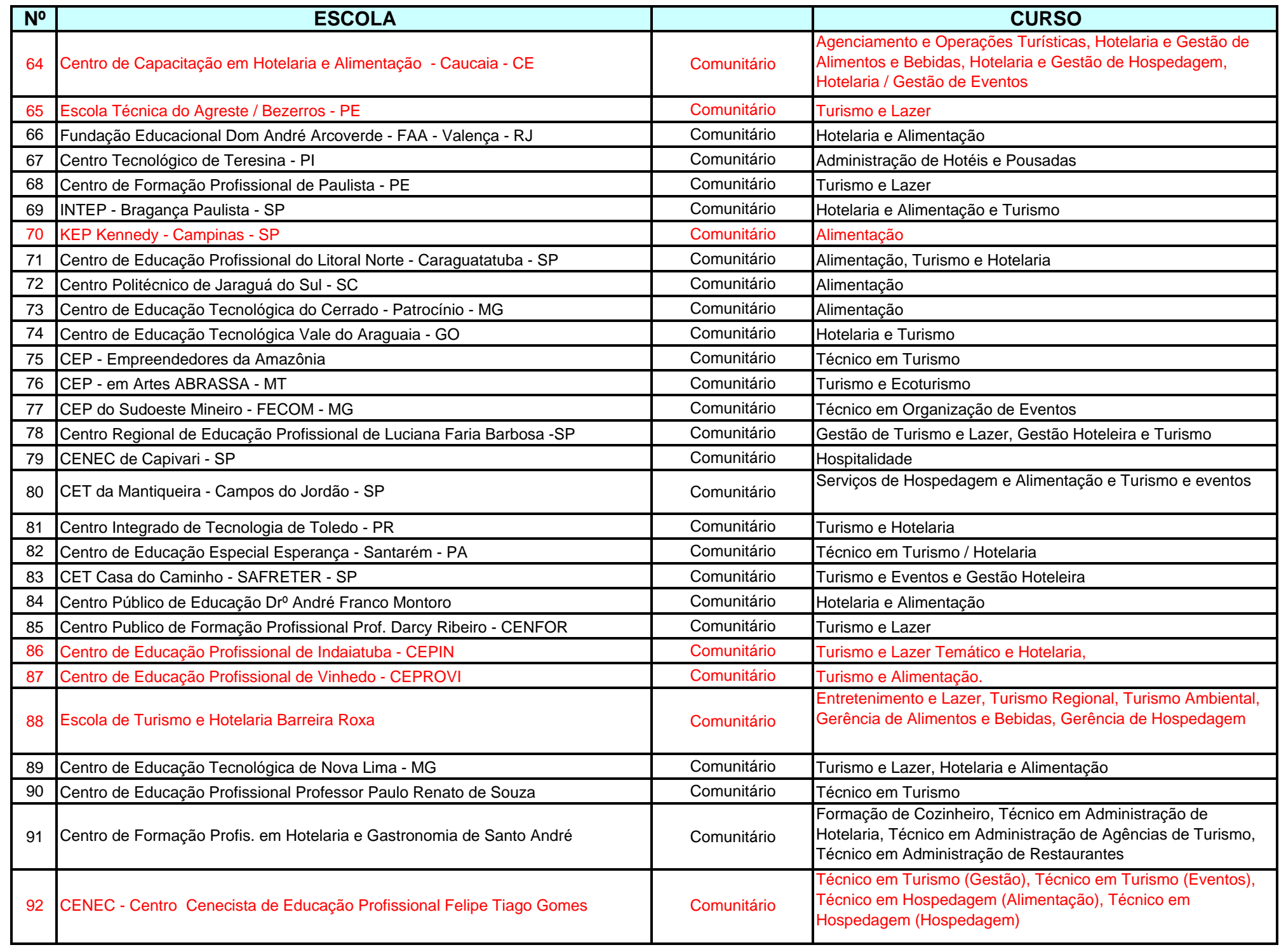


ESCOLAS PROEP

Cursos Técnicos na Área de Turismo e Hospitalidade

Gráfico Demonstrativo dos Cursos Técnicos de Turismo Hospitalidade 92 Escolas

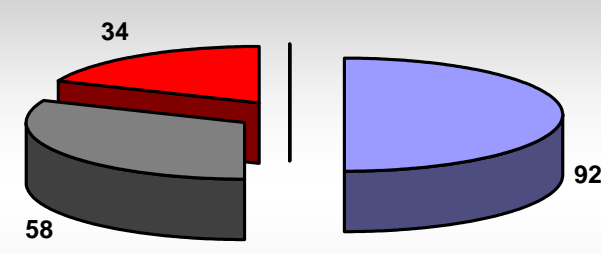

口Escolas com Cursos Técnicos em Turismo e Hospitalidade $\square$ Escolas em Fase de Execução $\square$ Escolas Inauguradas $\square$

Gráfico Demonstrativo das Habilitações Técnicas na Área de Turismo e Hospitalidade 144 Cursos

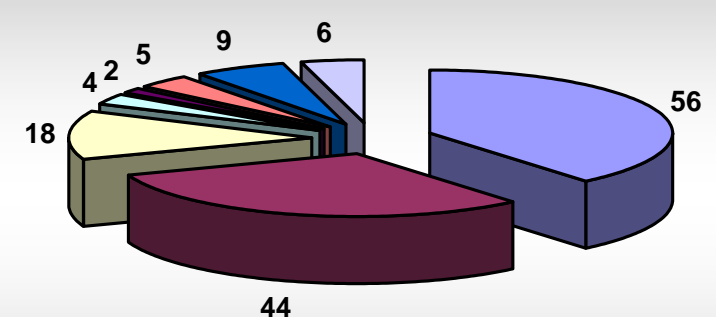

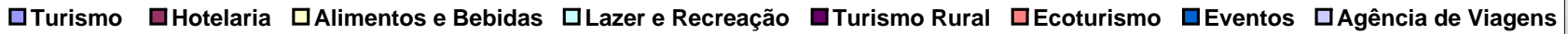

